\title{
TRANSMISSÃO DE TERRAS E DIREITOS DE PROPRIEDADE DESIGUAIS NAS FREGUESIAS DE IRAJÁ E CAMPO GRANDE (RIO DE JANEIRO, 1740-1856)'
}

\author{
Manoela Pedroza \\ Pós-doutoranda no Departamento de História da \\ Universidade de Montreal - Canadá.
}

\begin{abstract}
Resumo
Partindo do Rol de Desobriga de 1813 e com perspectiva microanalítica, o objetivo deste artigo é mostrar como os sítios nas vizinhanças dos engenhos de açúcar das freguesias de Campo Grande e Irajá foram a marca territorial de estratégias familiares locais, resultado de um complexo sistema de transmissão de bens que gerava "excluídos senhoriais” e criava direitos de propriedade desiguais intraparentela senhorial.

\section{Pallavras-chaves}

Sistema de transmissão de terras • excluídos senhoriais • direitos de propriedade.

\section{Abstract}

Based on rol de Desobriga of 1813 from a micro-analytical perspective, the objective of this article is to show that the ranches near the sugar mills in the Campo Grande civil parish during the 19th century were a territorial result of a property transmission system that excluded children from a master's family and that also offered different property rights within intra master kinship.
\end{abstract}

\section{Keywords}

Transmission system $\bullet$ master-excluded child $\bullet$ property rights.

\footnotetext{
${ }^{1}$ Os resultados discutidos nesse artigo são provenientes de pesquisa financiada pelo CNPq e PDEE-Capes e defendidos em 2008 como tese de doutorado em Ciências Sociais na Unicamp. A redação e revisão do artigo foram possíveis durante estágio pós-doutoral no ano de 2009 na Universidade de Montréal, financiado pelo Ministério dos Assuntos Estrangeiros do Governo do Canadá. Agradecemos especialmente ao professor Christian Dessureault pela supervisão e pelo apoio, mas o texto final é de nossa inteira responsabilidade. Quaisquer críticas, sugestões ou comentários são bem vindos pelo e-mail manoelap@gmail.com.
} 


\section{Introdução}

A paróquia de Campo Grande foi criada em 1673, com a fundação de uma capela particular nos campos de Bangu e, em 1834, ${ }^{2}$ fundou-se a freguesia que fazia parte do bispado da província do Rio de Janeiro, mais tarde integrada ao município neutro da corte. ${ }^{3}$ A freguesia de Campo Grande se inseria no Recôncavo da Guanabara, termo com o qual monsenhor Pizarro, em 1793, denominou toda a região do entorno da baía de Guanabara, onde prevalecia a plantação sobretudo de cana-de-açúcar.

Em 1813, o visitador Luiz Pereira Duarte, presbítero secular, percorreu a freguesia de Campo Grande e recenseou seus católicos, produzindo uma listagem que ficou registrada no livro de Desobriga ${ }^{0} 15 .{ }^{4}$ Nessa época, a freguesia comportava 432 fogos e tinha 3.058 moradores. O presbítero teve também o cuidado de dizer quais moradores eram senhores de engenho e, para os proprietários dos maiores plantéis, forneceu a quantidade de escravos, o número de famílias de agregados e os nomes dos membros de sua família nuclear estrita.

\footnotetext{
${ }^{2}$ As freguesias que compunham os sertões cariocas, ou "freguesias de fora", segundo o Ato Adicional de 1834, eram Campo Grande, Guaratiba, Jacarepaguá, Irajá, Inhaúma, Engenho Novo, Santo Antônio e Santa Cruz. Cf. MATTOS, Ilmar Rohloff de. Tempo saquarema: a formação do Estado imperial. São Paulo: Hucitec, 1987.

${ }^{3}$ A unidade territorial da "freguesia" tem sido o recorte por excelência dos trabalhos de história agrária no Brasil até o início do século XX, por constituir uma unidade administrativa relativamente homogênea, sobre a qual convergiam as ações tanto do cartório quanto da igreja/paróquia local. Para uma discussão sobre a delimitação de recortes espaciais em história agrária ver SILVA, Francisco Carlos Teixeira e LINHARES, Maria Yedda. Região e história agrária. Estudos históricos, v. 8, n. 15, 1995, p. 17-26. No caso da freguesia específica que será analisada aqui, Nossa Senhora do Desterro de Campo Grande, ver informações em SANTOS, Noronha. As freguesias do Rio Antigo. Rio de Janeiro: O Cruzeiro, 1965; ABREU, Antonio Izaías da Costa. Municípios e topônimos fluminenses: histórico e memória. Niterói: Imprensa Official do Estado do Rio de Janeiro, 1994; FRÓES, Jose Nazareth de Sousa e GELABERT, Odaléa Ranauro Ensenat. Rumo ao Campo Grande: por trilhas e caminhos. Rio de Janeiro: sem editora, 2004.

${ }^{4}$ A Desobriga foi instituída no Brasil em 1717, e era “o instrumento legal de que os bispos dispunham para o levantamento populacional nas suas Dioceses”. Todos os dados discutidos neste artigo são provenientes do rol de Desobriga, ou dos confessados, de 1813. O original desse documento foi extraviado do Arquivo da Cúria da Arquidiocese do Rio de Janeiro (doravante ACARJ), portanto nos baseamos na transcrição feita por José Nazareth Fróes, em seu livro publicado em 2004, que ao que parece, pôde contar com o documento original. Cf. FRÓES, Jose Nazareth de Sousa e GELABERT, Odaléa Ranauro Ensenat. Rumo ao Campo Grande: por trilhas e caminhos. Rio de Janeiro: sem editora, 2004, p. 101 a 115.
} 


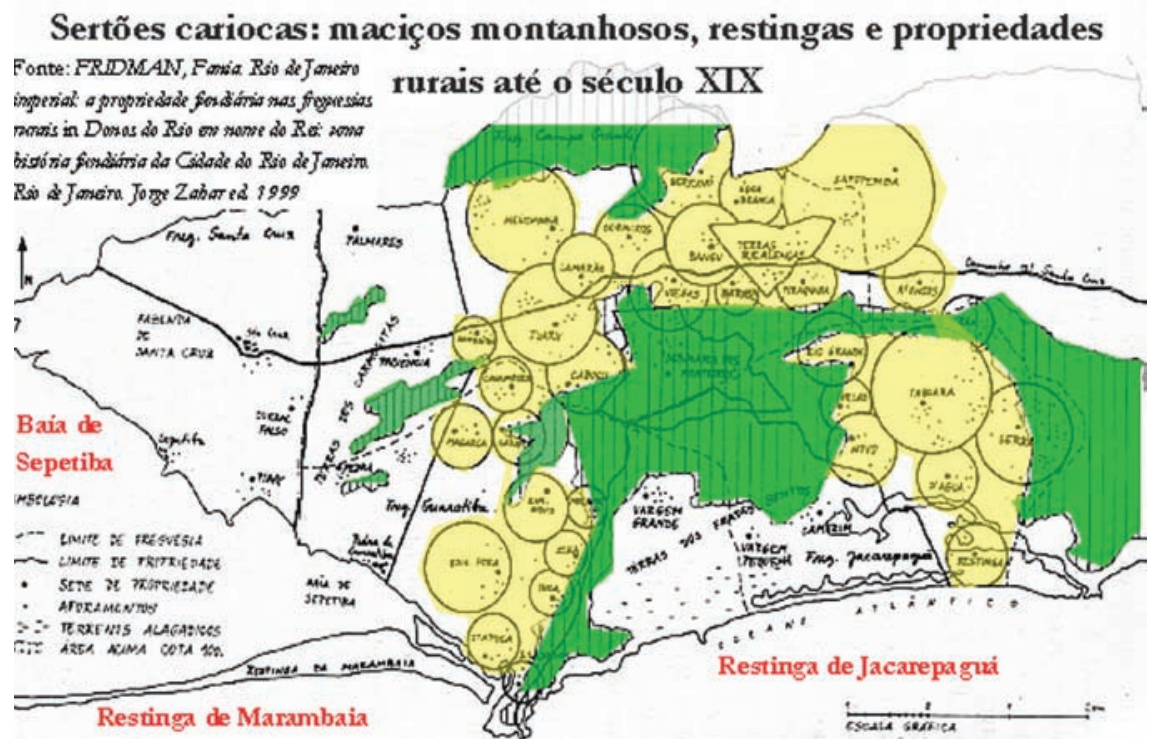

Figura 1 - Engenhos de açúcar nas freguesias de Campo Grande e Irajá. Fonte: Fridman, 1999.

Além disso, agrupou os fogos por locais que, no cruzamento com outras fontes, pudemos perceber que era sempre o nome de um engenho (nome este que, por sua vez, era derivado de um topônimo, quase sempre um rio). Esse fato poderia nos levar à conclusão equivocada de que os sitiantes agrupados na Desobriga em um mesmo local fossem moradores em terras desse engenho. Mas apresentamos uma explicação diferente. Embora coroasse de status seu possuidor, a compra ou a herança de um engenho não demarcava precisamente a propriedade sobre as terras de seu entorno, dando margem a inúmeros conflitos que seriam decididos no cabo-de-guerra do poder local.

Uma pequena amostra dessa diversidade pode ser vista num mapa da freguesia confeccionado por Fania Fridman a partir dos registros paroquiais de terra da freguesia. ${ }^{5}$ A autora preferiu representar o que chamaremos de "domínios” como círculos maiores ou menores, sobrepostos ou não a outros. Dentro

\footnotetext{
${ }^{5}$ FRIDMAN, Fania. Donos do Rio em nome do rei: uma história fundiária da cidade do Rio de Janeiro. Rio de Janeiro: Jorge Zahar, 1999.
} 
de cada um podem ser percebidos vários pontos, representando os declarantes daquele local, entre eles o engenho e a casa grande, centro da produção agrícola do lugar. Essa maneira de representar a configuração territorial local não traçou limites precisos entre propriedades, pois que, na prática, eles eram duvidosos e/ ou litigiosos. Além disso, a partir do tamanho do círculo, o mapa nos dá ideia da "zona de influência" maior ou menor de um determinado senhor de engenho, abarcando mais ou menos pontos, ou seja, estabelecendo relações de domínio (e de reconhecidos maiores direitos) com o conjunto de moradores em seu entorno. Por último, levando em consideração que inúmeros indivíduos declararam terras no mesmo local dos senhores-de-engenho, percebemos também a condição “nãoexclusiva” das “propriedades” da época, em que inúmeros “donos” pareciam usufruir daquele território, mesmo que em condições diferentes.

Por isso não julgamos ser possível falar em donos de fazendas, nem em grandes propriedades, nem numa justaposição de pequenas propriedades semelhante a bairros rurais. A organização territorial da freguesia era outra, baseada em direitos de propriedade desiguais que se sobrepunham num mesmo território. Por isso mesmo, não as chamaremos de propriedades, no sentido moderno do termo, mas de domínios, em que se sobrepunham vários direitos de propriedade, de uso e de acesso aos recursos, com limites fluidos. Ou, nos termos de época, poderíamos chamá-los de sesmarias.

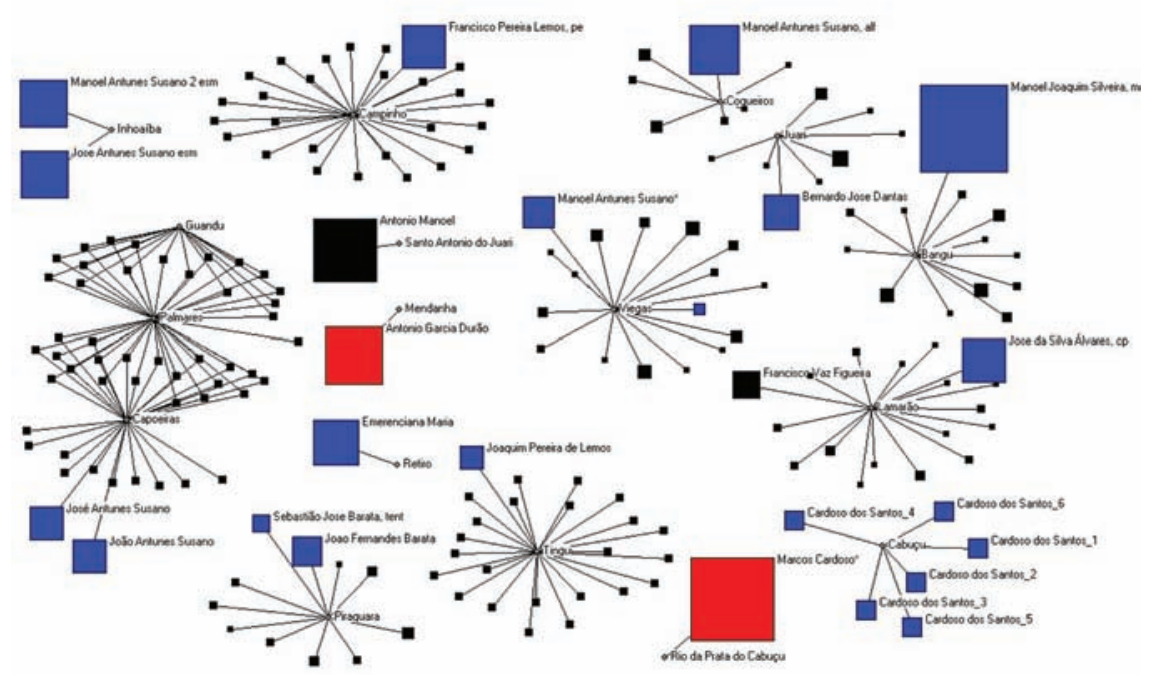

Figura 2- Senhores e sitiantes da freguesia de Campo Grande em 1813 - Fonte: Desobriga de 1813. 
O mapa de Fania Fridman e nossa representação de tipo réveillon da Desobriga de 1813 podem nos dar a ideia da complexidade da configuração territorial local. Nosso gráfico (figura 2) deve ser lido da seguinte maneira: os polos agregadores são os locais em que o padre chegava e no qual recenseava seus católicos. Nesses locais, cada casa, ou fogo, foi representada por um quadrado. Se os fogos pertenciam aos senhores de engenho, foram marcados em azul; outros moradores foram deixados em preto. Se, por acaso, o pároco não listou nenhum morador no mesmo local, seus senhores foram marcados em vermelho, para reforçar sua condição atípica de “únicos senhores”. O tamanho do quadrado representa a pujança produtiva da unidade doméstica. ${ }^{6}$

A Desobriga de 1813 confirmou a existência de grandes senhores de engenho exclusivistas, com grande número de escravos e nenhum morador, como Marcos Cardoso dos Santos, no Rio da Prata do Cabuçu, e Antônio Garcia Durão, no Mendanha (respectivamente com 124 e 83 UMOs). Havia também localidades dominadas por pequenos sitiantes provavelmente sem nenhum ou com poucos escravos, fora do espectro de um engenho, como Guandu e Palmares. Mas era no continuum formado entre esses dois polos que vivia a maior parte da população, ou seja, moradores com até quinze escravos, vizinhos a senhores-de-engenho com até setenta cativos, em média. De fato, além dos moradores que giravam em torno dos engenhos de açúcar das famílias senhoriais dos Cardoso dos Santos, Fernandes Barata, Antunes Suzano e Dantas, havia ainda, na vizinhança, 38 famílias de pequenos sitiantes na fazenda Palmares, 26 famílias na região de Campinho, e 20 na fazenda Viegas. O presbítero marcou a diferença entre esses pequenos sítios e as casas de agregados, que contabilizavam 45 em Santo Antônio do Juari e 32 no Rio da Prata do Cabuçu. Apenas nestes exemplos, que sabemos não abranger a totalidade, contabilizamos 196 famílias de sitiantes, dentre o total das 432 recenseadas na freguesia.

Mas a relação de moradores fornecida pela Desobriga de 1813 não nos deu segurança quanto às relações sociais dessas famílias com os senhores de enge-

\footnotetext{
${ }^{6}$ Para esse cálculo, convencionamos uma nova unidade de medida, a Unidade de Mão-de-Obra - UMO que agrega tanto o número de indivíduos da família (marido, esposa e filhos, já que não tínhamos a informação da idade de cada um), quanto o número de agregados e de escravos, quando havia. Para uma análise mais detalhada da força-de-trabalho dos sitiantes e sua relação com os engenhos do Recôncavo da Guanabara no século XVIII, ver PEDROZA, Manoela. Engenhocas da moral: uma leitura sobre a dinâmica agrária tradicional. Tese de doutorado, PPG Ciências Sociais, Unicamp, Campinas, 2008.
} 
nho. Portanto, a questão que motivou esta pesquisa foi: quem eram as dezenas de famílias de sitiantes na Desobriga de 1813? Que vínculos eles mantinham com os senhores de engenho vizinhos? Que direitos possuíam sobre as terras? Ao caminharmos nessa direção, chegamos a conclusões que expandiram nossa visão inicial sobre a "posição social” desses sitiantes. Por isso, nosso objetivo neste artigo será mostrar como os comportamentos e estratégias das famílias locais (senhoriais e de lavradores) convergiram na consolidação de redes de parentela complexas com expressão territorial nos sítios nas vizinhanças dos engenhos, e como esses sítios se inseriam na dinâmica socioeconômica local. Nosso objeto serão os excluídos senhoriais de Campo Grande que foram os agentes que, a nosso ver, em nível social, representavam os elos entre famílias de senhores e de lavradores e, em nível territorial, podem ser chamados de sitiantes. Definiremos melhor esses agentes no correr do texto.

\section{Fontes e metodologia}

O problema é que, para conhecer melhor essas pessoas, se colocam as dificuldades de uma "história vista de baixo": a falta de fontes produzidas pelos homens livres mais pobres. Em se tratando do Rio de Janeiro colonial, os pesquisadores podem dispor da obra do genealogista Carlos Rheigantz que coletou sistematicamente todos os registros paroquiais e compôs árvores genealógicas bastante ricas e completas, partindo dos primeiros “colonos” em terra carioca. $^{7}$

De nossa parte, escolhemos uma fonte inusual para um trabalho de história agrária: o Rol de Desobriga de 1813. Essa fonte apresenta uma grande limitação, qual seja, o fato de seu original ter sido extraviado e de termos acesso somente à transcrição feita por José Nazareth Fróes. ${ }^{8}$ Assim, nada podemos dizer da estrutura original do documento. Além disso, temos de ter em mente que o pároco não estava interessado em retratar a estrutura de posse da terra, mas que, sem ele querer, nos deu pistas bastante interessantes das relações entre

\footnotetext{
${ }^{7}$ RHEINGANTZ, Carlos Grandmasson. Primeiras famílias do Rio de Janeiro. Rio de Janeiro: Livraria Brasiliana, 1965. Esse trabalho foi tabulado em computador pelo Laboratório de Pesquisas em História Social - Liphis do IFCS-UFRJ, que compôs uma base de dados com mais de 16.000 entradas nominais de moradores do Rio de Janeiro. Agradecemos ao professor João Fragoso por ter nos permitido acesso a essa base de dados.

${ }^{8}$ FRÓES, Jose Nazareth de Sousa e GELABERT, Odaléa Ranauro Ensenat. Rumo ao Campo Grande: por trilhas e caminhos. Rio de Janeiro: sem editora, 2004.
} 
grupos sociais diversos. Primeiro, na medida em que "agregava” várias famílias a um determinado local, onde apenas uma era dona do “engenho”. Segundo, fornecendo o número de escravos de todas as famílias, o que nos permite classificar grosseiramente seu nível de riqueza. Além disso, o pároco também forneceu nome e sobrenome das famílias que não eram donas do engenho, dados importantes já que, até os relatórios governamentais do final do século XVIII, conseguíamos apenas saber os nomes e a quantidade de escravos dos senhores de engenho, mas nunca de quem morava a seu redor.

Em 1813, temos a primeira relação de nomes, sobrenomes, familiares e escravos dos católicos da freguesia, em seu conjunto. Essa relação foi nossa base para uma ampla reconstrução genealógica, matrimonial, clientelar e da transmissão do patrimônio que remontou a 1740, nos termos da microanálise, cujo resultado expusemos nos “diagramas patri-matrimoniais”, ao longo do texto. Antes da Desobriga de 1813, para além dos registros paroquiais, as informações que possuímos são pontuais e muito fragmentárias: basicamente dois inventários de lavradores ${ }^{9}$ e o de um senhor de engenho. ${ }^{10}$ Sem a Desobriga, portanto, continuaríamos apenas a rascunhar a história isolada das famílias senhoriais e seu patrimônio ou precários quadros de fortunas locais baseados em pouquíssimos inventários de pobres, sem conseguir relacionar esses dois mundos.

Avaliando a representatividade de nossa amostragem, seria necessário traçar a genealogia de todos os moradores listados em 1813, uma multidão ao redor dos engenhos, para podermos conhecer com precisão suas origens, suas posses e suas relações com todos os senhores de engenho vizinhos. Isso não é possível, já que apenas uma minoria deles foi registrada com seus nomes e sobrenomes em 1813, o que impede sua busca onomástica em quaisquer fontes anteriores, mesmo se estas existissem. Por isso, metodologicamente este artigo preferiu lidar com redes, famílias, estratégias e atores, tentando fugir do tipo de trabalho que prima pela quantificação e classificação que, usando as palavras de Levi, provocam sempre a sensação de demasiado impessoais e imprecisos. ${ }^{11}$

\footnotetext{
${ }_{9}^{9}$ Arquivo Nacional (doravante AN). Fundo Inventários. Nome: Miguel Cardoso Castel Branco. Ano 1797. Notação 8.993; e Apelação cível de Anna Joaquina do Nascimento. Ano 1847. Caixa 3629, número 4.116.

${ }^{10}$ AN. Fundo Inventários. Nome: Ana Maria de Jesus. Inventariante: João Pereira Lemos. Ano 1795. Notação 10, caixa 3636.

${ }^{11}$ Cf. LEVI, Giovanni. Centro e periferia di uno stato assoluto: tre saggi su Piemònte e Liguria in età moderna. Torino: Rosenberg and Sellier, 1981.
} 
Tentaremos chegar a um esquema analítico que tenha por base as lógicas de ação daqueles sujeitos, sem a preocupação de abranger quantitativamente toda a população de Campo Grande, mas sim de ressaltar alguns comportamentos que podem ser verificados mesmo dentro de uma seleção incompleta.

Ao longo deste texto, buscaremos comprovar as seguintes hipóteses: primeiro, a de que os sitiantes listados na Desobriga de 1813 eram os excluídos senhoriais, ou seus descendentes, casados com lavradores locais e estabelecidos nas franjas da propriedade familiar; segundo, que sítios são a expressão territorial de estratégias matrimoniais envolvendo a composição de redes de parentela complexas e desiguais; terceiro, que os sitiantes são a mediação entre desigualdade econômica, desigualdade de direitos sobre as terras (do ponto de vista da família senhorial) e as diversas possibilidades de ascensão ou queda de status social (do ponto de vista das famílias de lavradores), possíveis naquele contexto ${ }^{12}$ por último, veremos que a estabilidade dos sitiantes em terras formalmente alheias e na condição mais favorável do que a de meros agregados foi possível não porque tivessem títulos, mas porque eram respeitados e reconhecidos pela comunidade do seu entorno e faziam parte dos circuitos parentais e patrimoniais mais amplos.

Para tanto, este trabalho lida com alguns conceitos que merecem ser explicitados. O primeiro é o de estratégia, como o produto do senso prático, o sentido do jogo que se adquire desde a infância, participando das atividades sociais em um contexto social e historicamente definido. ${ }^{13}$ Faremos também constantemente referência às famílias senhoriais. Segundo João Fragoso, ${ }^{14}$ trata-se de uma família na qual algum descendente masculino se tornou, em algum momento, senhor de engenho. Ainda lançamos mão do conceito de região colonial, como espaço socialmente construído num determinado tempo

\footnotetext{
${ }^{12}$ Para uma análise da "mobilidade social” no Antigo Regime europeu, ver LEVI, Giovanni. Carrières d'artisans et marché du travail à Turin (XVIII-XIX siècles). Annales ESC, v. ano 45, n. 6, 1990, p. 1351-1402, e HESPANHA, António Manuel. A mobilidade social na sociedade de Antigo Regime. Tempo, v. 11, n. 21, 2006, p. 121-143.

${ }^{13}$ Segundo Bourdieu, “O bom jogador (...) faz a todo instante o que deve ser feito, o que o jogo demanda e exige. Isso supõe uma invenção permanente, indispensável para se adaptar às situações indefinidamente variadas, nunca perfeitamente idênticas. O que não garante a obediência mecânica à regra explicita codificada (quando ela existe)”. Cf. BOURDIEU, Pierre. Das regras às estratégias. In: Coisas ditas. São Paulo: Brasiliense, 1990, p. 81-2.

${ }^{14}$ Cf. FRAGOSO, João Luís Ribeiro. A nobreza da República: notas sobre a formação da primeira elite senhorial do Rio de Janeiro (séculos XVI e XVII). Topoi: Revista de História do Programa de Pós-Graduação em História Social da UFRJ, v. 1, 2000.
} 
histórico. ${ }^{15}$ Para terminar, entendemos como reprodução social o resultado do processo através do qual uma população, sobre um dado território, consegue perpetuar as estruturas e relações que a constituem.

Sabendo que essa população se organiza concretamente em torno de famílias, podemos dizer que a reprodução social de um grupo se produz, microanaliticamente, através dos meios utilizados por uma família para transportar de uma geração à outra um capital que permita o estabelecimento dos descendentes, isto é, sua inserção nas hierarquias sociais. ${ }^{16} \mathrm{O}$ conjunto desses mecanismos forma um sistema de transmissão, que engloba todas as decisões e disposições pelas quais os bens de uma família passam de uma geração para a outra, e é resultante de um conjunto de constrangimentos e fatores costumeiros ou jurídicos que pesam sobre essa operação e ditam suas fórmulas. ${ }^{17}$ Em se tratando de uma sociedade rural, o sistema de transmissão e o sucesso da reprodução social estão bastante vinculados aos problemas ligados à transmissão da terra. ${ }^{18}$ Sobre a transmissão da terra pesam estratégias de sucessão, isto é, a maneira específica de transmitir o status e os papéis sociais de uma geração a outra, e estratégias de herança, isto é, as formas de transmitir o direito de propriedade. ${ }^{19}$ Via de regra, a sucessão é mais importante para a sociedade camponesa, já que estipula a maneira pela qual se dará o acesso à terra, a perpetuação do grupo doméstico e da identificação coletiva.

\section{Revisão de bibliografia: os excluídos patrimoniais do campo}

Historicamente, as dificuldades de reprodução social das famílias que dependem da terra como fonte de trabalho, renda ou status, provêm, sobretudo, do dilema colocado no momento da partilha dos bens, entre herança preferencial

\footnotetext{
${ }^{15}$ Cf. MATTOS, Ilmar Rohloff de. Tempo saquarema: a formação do Estado imperial. São Paulo: Hucitec, 1987.

${ }^{16}$ BOUCHARD, Gérard. Les systèmes de transmission des avoirs familiaux et le cycle de la société rurale au Québec du XVII au XXe siècle. Histoire sociale - Social history, v. 16, n. 31, 1983, p. 35-60.

${ }^{17}$ BOUCHARD, Gérard. L'étude des structures familiales préindustrielles: pour un renversement des perspectives. Revue d'histoire moderne et contemporaine, v. 28, 1981, p. 544-571.

${ }^{18}$ BOUCHARD, Gérard. Les systèmes de transmission des avoirs familiaux et le cycle de la société rurale au Québec du XVII au XXe siècle. Histoire sociale - Social history, v. 16, n. 31, 1983, p. 35-60.

${ }^{19}$ AUGUSTINS, Georges. Esquisse d'une comparaison des systèmes de perpétuation des groupes domestiques dans les societés paysannes européenes. Archives Européenes de Sociologie, v. XXIII, n. 1, 1982, p. 39-72.
} 
(isto é, a escolha de um filho para ser dono de todos os bens) ou fragmentação do patrimônio (partilhando-o igualmente entre todos os herdeiros). Essas dificuldades ficam ainda mais evidentes ao lidarmos com famílias onde o número de filhos é maior do que as possibilidades concretas de se contrair casamentos vantajosos, o que é a regra geral. Nesse caso, o risco de fragmentação do patrimônio é maior.

O problema é bastante antigo e não apenas dos brasileiros. Na Europa, em contextos de fronteira completamente fechada, a principal estratégia de reprodução social das famílias rurais foram as alianças matrimoniais vinculadas a um sistema de transmissão chamado de preciputário, ou completamente desigual entre os herdeiros. ${ }^{20}$ Particularmente para as famílias da elite fundiária, prevalecia a lógica de um “casamento prudente”, no qual predominavam cálculos patrimoniais que deviam atingir dois objetivos: a defesa da propriedade e também da linhagem familiar. Além das alianças matrimoniais seletivas, o celibato forçado era outra saída para diminuir a quantidade de herdeiros e a consequente fragmentação das terras. Ele podia ser relativo, retardando ao máximo a idade do casamento dos filhos, ou absoluto, enviando para carreiras religiosas quantos filhos e filhas fossem necessários para manter íntegra a herança do preferido. ${ }^{21}$ Esse sistema de transmissão tem todas as cores do Antigo Regime e pode ser vislumbrado mesmo nos trópicos. ${ }^{22}$ É mister reconhecer que

\footnotetext{
${ }^{20}$ Nesse caso, estamos diante de sistemas de transmissão de sucessão única e herança preferencial, isto é, aqueles em que, para cada geração, há apenas um casal no grupo doméstico, e o papel do sucessor é dado no dia em que ele leva o cônjuge para viver na casa paterna. Os sistemas de transmissão desse tipo são também chamados de sistemas maison, e subsistem sobretudo na região dos Alpes europeus. Na transmissão patrimonial desse tipo, tudo é indissociável: patrimônio, exploração, nome e linhagem doméstica. Por isso, sucessor e herdeiro são a mesma pessoa. Numa situação ideal de um casal com um casal de filhos, o sistema matrimonial lida com dois tipos de casamentos: os dos sucessores, que asseguram a perpetuação das respectivas maisons e merecem todo cuidado; e os outros, que visam apenas a garantir o futuro dos outros filhos, para os quais pequenos dotes bastam. Os filhos não sucessores podem casar, mas não terão terra. Para maiores detalhes ver BOURDIEU, Pierre. Célibat et condition paysanne. Études Rurales, n. 5-6, 1962, p. 32-135; AUGUSTINS, Georges. Esquisse d'une comparaison des systèmes de perpétuation des groupes domestiques dans les sociétés paysannes européennes. Archives Européennes de Sociologie, v. XXIII, n. 1, 1982, p. 39-72; BARTHELEMY, Tiphaine. Les modes de transmission du patrimoine. Synthèse des travaux effectués depuis quinze ans par les ethnologues de la France. Études Rurales, v. 110-111-112, 1988.

${ }^{21}$ Cf. MALATESTA, Maria. Le aristocrazie terriere nell'Europa contemporanea. Roma/Bari: Editori Laterza, Quadrante Laterza 101, 1999.

${ }^{22}$ Cf. SILVA, Maria Beatriz Nizza da. Sistema de casamento no Brasil colonial. São Paulo: Edusp, Coleção Coroa Vermelha, 1984.
} 
os sistemas preciputários produzem excluídos em cada geração. O conjunto de pesquisas sobre esse grupo social apontou que, no meio rural, a exclusão foi quase sempre sinônimo de marginalização, mobilidade espacial ou êxodo rural definitivo para um filho. ${ }^{23}$

O caso brasileiro, entretanto, trouxe soluções novas para esse velho problema. As possibilidades de incorporação fundiária possibilitadas por uma fronteira aberta teriam sido aproveitadas até quando novas terras não puderam ser mais arroteadas e passou-se à situação parecida com o caso europeu, ou seja, da incorporação fundiária ao patrimônio individual majoritariamente por herança ou compra. Em outras palavras, a grande novidade da colônia era a abundância de terras $^{24}$ e a consequente possibilidade da instalação de uma geração em terrenos diferentes da anterior, fenômeno totalmente estranho à vivência camponesa europeia. Na bibliografia brasileira é quase consensual que a elasticidade do território teria diminuído a demanda dos herdeiros por seu quinhão dos bens de raiz da família, já que a possibilidade do apossamento tornava o patrimônio dos filhos parcial ou totalmente independente das terras dos pais. ${ }^{25} \mathrm{~A}$ imagem

\footnotetext{
${ }^{23} \mathrm{Em}$ 1997, historiadores franceses e quebequenses se reuniram para discutir precisamente esse problema, na tentativa de traçar continuidades e rupturas entre a França e sua colônia americana. Seu principal desafio era entender os efeitos da exclusão da herança e o destino dos excluídos nas famílias camponesas. Como pontos em comum, os pesquisadores remarcaram a raridade da exclusão total de um filho baseada somente na vontade testamentária do pai e a disseminação da exclusão das filhas pela concessão de um dote de casamento. Os trabalhos foram reunidos em um livro, Cf. BOUCHARD, Gérard; DICKINSON, John; GOY, Joseph (dir). Les exclus de la terre en France et au Québec XVIIe-XXe siècles. La reproduction familiale dans la différence. Sillery: Septentrion, 1998. ${ }^{24}$ Abundância ou carência de braços e fronteira aberta ou fechada não são dados do mundo físico, mas algo socialmente produzido. No Brasil, a "abundância de terras”, ou as "terras livres” foram produtos de relações de força, com a expulsão, extermínio ou genocídio da população nativa. No Rio de Janeiro, segundo fontes dos séculos XVI ao XVIII, para uma família pertencer à nobreza da terra ela devia descender de conquistadores, isto é, ter algum ancestral pertencido às expedições comandadas por Mem de Sá nas lutas contra os franceses e tamoios no século XVI. Uma das primeiras formas de benefício solicitadas pelos conquistadores e seus descendentes foram braços e terras, os primeiros tornados cativos, e as segundas, livres, transformados respectivamente em "presas de guerra” e nas maiores sesmarias. Cf. FRAGOSO, João Luís Ribeiro. Principais da terra, escravos e a república: o desenho da paisagem agrária do Rio de Janeiro seiscentista. Ciência e Ambiente, v. 33, 2006, p. 6; FRAGOSO, João Luís Ribeiro. A nobreza da República: notas sobre a formação da primeira elite senhorial do Rio de Janeiro (séculos XVI e XVII). Topoi: Revista de História do Programa de Pós-Graduação em História Social da UFRJ, v. 1, 2000. MATTOS, Ilmar Rohloff de. Tempo saquarema: a formação do Estado imperial. São Paulo: Hucitec, 1987.

${ }^{25}$ Para a discussão sobre a abundância de braços no caso paulista, ver SILVA, Sergio. Expansão cafeeira e origens da indústria no Brasil. São Paulo: Alfa Omega, 1976; MOMBEIG, Pierre. Pioneiros e fazendeiros de São Paulo. Tradução de Ary França e Raul Andrade e Silva. São Paulo: Hucitec - Polis, 1984. Sobre fronteira e expansão capitalista no Brasil ver VELHO, Otávio Gui-
} 
subjacente a essa discussão é que as famílias em regiões de "fronteira aberta" se movimentassem entre terras “com dono” e terras "sem dono”, propriedades ou posses, ocupadas ou livres, enfim, num espaço claramente dividido entre o que poucos poderiam herdar e o que muitos deveriam ocupar.

Mas a realidade, ao menos para o nosso estudo de caso, foi bastante mais complexa. Por exemplo, João Fragoso, ao estudar a família de um senhor de engenho no Rio de Janeiro do século XVIII, notou que cinco de seus primos moravam na sua fazenda, o que abria a possibilidade de existir um sistema de transmissão do patrimônio que dava abrigo aos parentes de uma larga família, hierarquicamente constituída. ${ }^{26}$ Inicialmente nos pareceu conflitante a convivência tão próxima entre irmãos senhores e sitiantes, mas seguimos essa pista.

Ao final de nosso estudo de caso, percebemos que a solução campo-grandense para o dilema da transmissão fundiária e da consequente reprodução social dos grupos ligados à terra foi original e bastante estável no tempo, adaptando a dinâmica agrária local a uma lógica extraeconômica. A partir dos casos específicos dos excluídos senhoriais da freguesia de Campo Grande, gostaríamos de mostrar ao leitor de que maneira os diferentes extratos de uma parentela imprimiam suas marcas num mesmo território, e entender os múltiplos direitos que se definiam sobre esse território apossado a partir da posição ocupada pelo apossador em redes sociais locais. Essa discussão nos levará, finalmente, ao estatuto dos moradores no censo paroquial de 1813.

lherme. Capitalismo autoritário e campesinato. São Paulo: Difel, 1974; MARTINS, José de Souza. O cativeiro da terra. São Paulo: Hucitec, 1986; MARTINS, José de Sousa. A vida privada nas áreas de expansão da sociedade brasileira. In: NOVAIS, Fernando e SCHWARZ, Lília Moritz (eds). História da vida privada no Brasil: Contrastes da intimidade contemporânea. São Paulo: Companhia das Letras, 1994; MARTINS, José de Souza. Fronteira: a degradação do outro nos confins do humano. São Paulo: Hucitec, 1997. Fizemos uma discussão sobre a elasticidade da fronteira - no caso, através do termo de época, o sertão - e a possibilidade de áreas "fechadas" se “abrirem” em nossa dissertação de mestrado. PEDROZA, Manoela. Terra de resistência: táticas e estratégias camponesas nos sertões cariocas (1950-1968). Dissertação de mestrado, PPG História, UFRGS, Porto Alegre, 2003, capítulo 2; Para uma análise pormenorizada da relação entre posse e herança, no contexto atual do Vale do Ribeira, ver PAOLIELLO, Renata Medeiros. As tramas da herança: da reprodução camponesa às atualizações dos sentidos da transmissão da terra. Tese de doutorado, PPG Antropologia Social, USP, São Paulo, 1998.

${ }^{26}$ FRAGOSO, João Luís Ribeiro. Capitão Manuel Pimenta Sampaio, senhor do Engenho do Rio Grande, neto de conquistadores e compadre de João Soares, pardo: notas sobre uma hierarquia social costumeira (Rio de Janeiro, 1700 - 1760). In: XXIII Simpósio Nacional da ANPUH, São Leopoldo, RS., 2007. 


\section{Os casos}

Partindo concretamente de poucas famílias que não tinham engenhos de açúcar, mas que foram listadas com nome e sobrenome na Desobriga de 1813, e buscando esses nomes em outras fontes (sobretudo nos registros paroquiais e inventários), pudemos traçar o histórico da ocupação de alguns indivíduos, seus vínculos com a terra e com o trabalho, suas relações parentais e a forma com que transmitiram seu patrimônio. Por limitações de espaço, apresentaremos apenas dois casos que consideramos emblemáticos, o de um núcleo de lavradores ligados ao engenho de Sapopemba, na freguesia de Irajá, e de outro ligado ao engenho das Capoeiras, na freguesia de Campo Grande, no Rio de Janeiro.

\section{Antônio Cardoso Castel Branco, o primo pobre de Sapopemba}

A partir da década de 1740, podemos perceber a proximidade cotidiana de duas famílias - Castel Branco e Pereira Lemos - pelos registros de batismos de seus membros e de seus escravos. ${ }^{27}$ Como Antônio e seus dez filhos tinham alguns escravos, mas não consta em nossos registros que tenham sido senhores de algum engenho, julgamos que pudessem ter se especializado na plantação de cana para o engenho de Sapopemba, o que explicaria a proximidade entre seus plantéis e o de seu senhor na forma de compadrios cruzados.

Devemos aqui abrir um parênteses para explicitar de que forma estamos interpretando as relações de compadrio entre famílias que, mesmo de desiguais níveis econômicos, possuíam escravos e trabalhavam lado a lado nos partidos de cana do engenho. Para atingir nossos objetivos, gostaríamos de avaliar de que forma os compadrios entre homens livres - senhores de engenho e lavradores - e seus escravos criaram vínculos entre suas famílias, e de que forma essas relações de parentesco ritual também construíram a estrutura agrária local.

Refletindo sobre a construção de relações sociais através da linguagem do compadrio escravo num estudo de caso concreto, ${ }^{28}$ verificamos que, primeiro,

\footnotetext{
${ }^{27}$ ACARJ. AP 343 (1740-1759), folhas 13-frente, 9-frente, 15-frente, 20-frente, 21-verso, 32-verso, 38-frente, 48-verso, 51 -frente, 59-verso, 69-frente, 68-frente, 76-frente, 80 -frente, 75 -frente, 81 -frente, 83-frente, 84-frente, 89-verso, 87-verso, 92-frente, 94-verso, 93-frente, 96-verso, 99-verso, 102-frente, 102-verso, 104-frente, 110-verso, 109-verso, 112-frente, 111-frente, 113-frente, 118-verso, 120 -frente. ${ }^{28}$ Foram analisados os livros de registro de batismos de livres e os de escravos das freguesias de Irajá e Campo Grande para as décadas de 1740 e 1750. Foram também coletados, a título de amostragem, os batismos de livres de Campo Grande entre 1835 e 1849, e entre 1874 e 1883 . Ver ACARJ, livros de registro de batismo.
} 
alguns escravos batizavam filhos de escravos de outros plantéis e mesmo filhos de homens livres e pobres, desde que ambos os compadres também se relacionassem com o seu próprio senhor. Em outras palavras, confirmando os estudos de Martha Hameister, vimos que os compadres dos escravos foram escolhidos a partir da mesma malha de relações sociais das famílias senhoriais às quais estavam compulsoriamente submetidos, relações essas que abarcavam tanto homens livres vinculados ao engenho quanto escravos de outros plantéis amigos. ${ }^{29}$ Esse parece ser também o perfil dos batizados em que se envolveu o capitão João Pereira Lemos, senhor de Sapopemba. Por exemplo, suas escravas foram madrinhas dos filhos dos escravos de Antônio Cardoso Castel Branco. ${ }^{30}$

Sobre a linguagem do compadrio entre homens livres pobres e senhores locais existem menos pesquisas, para além do axioma bastante disseminado de que os batizados consolidariam relações de tipo clientelista. Em nosso caso, vimos que o senhor nunca batizou diretamente nem seus escravos nem os escravos dos seus sitiantes, fato que pode estar relacionado, também segundo Hameister, ao distanciamento necessário para exercer tanto a violência quando a venda daquele cativo. ${ }^{31}$ Ele batizava, no máximo, e poucas vezes, os filhos de seus lavradores livres. Já homens livres e pobres batizavam corriqueiramente os escravos desse senhor, e davam seus filhos para serem batizados pelo mesmo senhor.

\footnotetext{
${ }^{29}$ Cf. HAMEISTER, Martha Daisson. Para dar calor à nova povoação: estudo sobre estratégias sociais e familiares a partir dos registros batismais da vila do Rio Grande (1738-63). Tese de doutorado, PPG História, UFRJ, Rio de Janeiro, 2006. João Fragoso defendeu a hipótese de que havia 'madrinhas-rainha' entre as escravas dos senhores, aquelas mais solicitadas como madrinhas dos filhos de escravos e livres na vizinhança, entre tantas outras, reproduzindo a diferenciação social mesmo dentro das senzalas. Cf. FRAGOSO, João Luís Ribeiro. Capitão Manuel Pimenta Sampaio, senhor do Engenho do Rio Grande, neto de conquistadores e compadre de João Soares, pardo: notas sobre uma hierarquia social costumeira (Rio de Janeiro, 1700 - 1760). In: XXIII Simpósio Nacional da ANPUH., São Leopoldo, RS. 2007.

${ }^{30}$ ACARJ. AP 343 (1740-1759), folhas 39-verso, 33-frente. Analisando as redes de compadrio entre senhores e homens livres e pobres, eu defendo que foram os primeiros tijolos a construírem vínculos entre as famílias de lavradores e as famílias senhoriais envolvidas na produção de açúcar nos engenhos do Rio de Janeiro, no século XVIII. Cf. PEDROZA, Manoela. Engenhocas da moral: uma leitura sobre a dinâmica agrária tradicional. Tese de doutorado, PPG Ciências Sociais, Unicamp, Campinas, 2008.

${ }^{31} \mathrm{O}$ objetivo deste artigo não é a análise mais aprofundada do fenômeno do compadrio entre escravos. Para uma discussão sobre esse assunto, ver FRAGOSO, João Luís Ribeiro. Principais da terra, escravos e a república: o desenho da paisagem agrária do Rio de Janeiro seiscentista. Ciência e Ambiente, v. 33, 2006; HAMEISTER, Martha Daisson. Para dar calor à nova povoação: estudo sobre estratégias sociais e familiares a partir dos registros batismais da vila do Rio Grande (1738-63). Tese de doutorado, PPG História, UFRJ, Rio de Janeiro, 2006.
} 


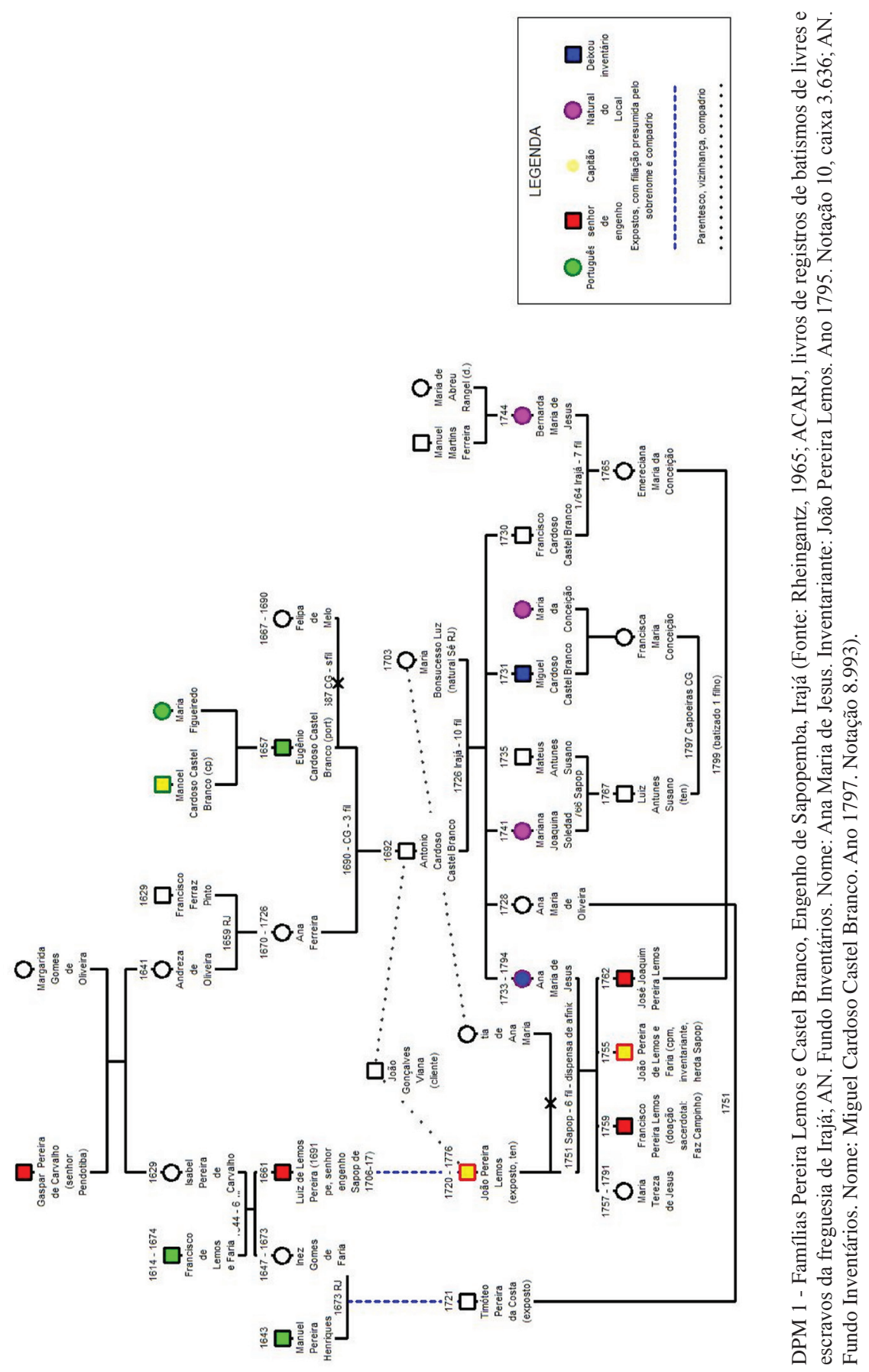


Nesse ponto, é preciso ter em mente que a estrutura de fornecimento da cana necessária para a produção de açúcar pressupunha uma ampla rede de lavradores livres em seus partidos, ao redor do engenho. ${ }^{32}$ Esse fato não era apenas uma necessidade econômica, mas o resultado de uma opção e da ação ativa dos sujeitos envolvidos na produção de vínculos que sobrepassassem o trabalho. Então, para os fins desse trabalho, consideramos que estes seriam atos voluntários para criação de parentesco ritual que tiveram o objetivo de estruturar, hierarquicamente, uma dita “casa senhorial”, de um modo mais amplo do que apenas o mundo da produção de seu engenho. Neste caso, as relações de compadrio iam à direção de inserir o lavrador e sua família, mesmo que de maneira subordinada, nessa rede de relações sociais que contavam, inclusive, com a participação ativa de ambos os plantéis na escolha de padrinhos livres.

Mas podemos perceber que, com o passar dos anos, a família Cardoso Castel Branco conseguiu efetivamente dar um salto no seu status de "compadres pobres” para realmente fazer parte da família Pereira Lemos por vínculos matrimoniais. O capitão João Pereira Lemos se casou, ao final de 1740, provavelmente com a cunhada de Antônio Cardoso Castel Branco, mas ela faleceu em seguida. A nova tentativa, pouco tempo depois, deu mais certo. João se casaria, em segundas núpcias, com Ana Maria de Jesus, enquanto seu primo Timóteo se casaria com Ana Maria de Oliveira, ambas filhas de Antônio. Nem todos os vizinhos pobres tiveram essa mesma sorte. A que se deve isso?

Antônio Cardoso Castel Branco, lavrador, e João Pereira Lemos, capitão e senhor, também eram primos em segundo grau. Isso porque o pai de Antônio, português, havia se casado com uma prima pobre do pai de João, e se estabelecido desde 1690 em terras próximas ao engenho de Sapopemba, já que, desde aquela época, seus escravos trocavam afilhados entre si. ${ }^{33}$ Os ascendentes comuns das duas famílias eram duas irmãs (Andreza de Oliveira e Izabel Pereira de Carvalho) que se estabeleceram em Irajá, onde nasceram e se casaram seus filhos - dentre os quais o pai de João e a mãe de Antônio -, mesmo que

\footnotetext{
32 SAMPAIO, Antônio Carlos Jucá de. Na encruzilhada do império: hierarquias sociais e conjunturas econômicas no Rio de Janeiro (1650-1750). Rio de Janeiro: Arquivo Nacional Prêmio Arquivo Nacional de Pesquisa, 17, 2003, p. 98-99; FRAGOSO, João Luís Ribeiro. Para que serve a história econômica. Estudos Históricos, v. 29, 2002, p. 9; COSTA, Iraci. Notas sobre a posse de escravos nos engenhos e engenhocas fluminenses (1778). Revista do Instituto de Estudos Brasileiros, n. 28, 1988, p. 113.

${ }^{33}$ ACARJ. AP-343 (Irajá, 1740 a 1759).
} 
depois tenham se diferenciado economicamente em senhores de engenho e lavradores necessários a esse mesmo engenho. ${ }^{34}$ Portanto, a relação desigual, mas estratégica, entre primos, vizinhos e envolvidos na produção do engenho de Sapopemba se completou em 1751, quando Antônio deu duas de suas filhas para se casarem com João Pereira Lemos e seu primo.

Vendo sob a ótica de uma classificação socioeconômica estática, tudo se restringiria à constatação da construção histórica da concentração de terras e da desigualdade socioeconômica entre senhores e lavradores. Mas, na prática, ramos ou classes tão diferentes batizaram-se e até casaram-se entre si. Portanto, se, economicamente, Antônio Cardoso Castel Branco se igualava a muitos outros clientes ou aliados pobres dos senhores de Sapopemba (que chegavam apenas a batizar escravos do senhor), nos parece que ele soube ativar relações parentais longínquas, mas estratégicas, para criar uma preferência matrimonial para suas filhas e os Pereira Lemos. ${ }^{35}$ Daí defendermos a hipótese de que, ao lado da estrutura fundiária dos engenhos de açúcar do século XVIII, havia uma dinâmica parental que criou pontes entre o mundo do trabalho, da terra e da parentela.

\section{0 destino dos irmãos pobres}

Além disso, por essas pontes, alguns pobres da região puderam ativar origens comuns como trampolim para ascensão socioeconômica. Ana Maria de Jesus, filha de Antônio Cardoso Castel Branco, foi meeira dos bens do marido, o capitão e senhor do engenho de Sapopemba, João Pereira Lemos. ${ }^{36}$ Seu inventário, de 1794, nos dá uma visão global do patrimônio da família: 64.590.550 réis. ${ }^{37}$ Alguma dúvida de que Ana Maria de Jesus foi catapultada pelo casamento? E pensar que, antes de se casar, era madrinha dos filhos dos

\footnotetext{
${ }^{34}$ Eram duas filhas do mesmo senhor de engenho, Gaspar Pereira de Carvalho. Cf. RHEINGANTZ, Carlos Grandmasson. Primeiras famílias do Rio de Janeiro. Rio de Janeiro: Livraria Brasiliana, 1965, tomo II, p. 71-72.

${ }^{35}$ RHEINGANTZ, Carlos Grandmasson. Primeiras famílias do Rio de Janeiro. Rio de Janeiro: Livraria Brasiliana, 1965, tomo II, p. 71.

${ }^{36}$ As Ordenações Filipinas, vigentes no Império Português a partir de 1603, sancionavam o costume de que os casamentos fossem contratos de meação, ou seja, que o casal partilhasse todos os seus bens. Cf. Ordenações Filipinas. Rio de Janeiro: Editor Cândido Mendes de Almeida, 1870, livro 4, título XCIV: Como o marido ou mulher casados succedem hum ao outro; e título XLVI: Como o marido e mulher são meeiros em seus bens, p. 832. A íntegra das Ordenações Filipinas pode ser acessada no sítio: http://www1.ci.uc.pt/ihti/proj/filipinas/ordenacoes.htm.

${ }^{37}$ AN. Fundo Inventários. Nome: Ana Maria de Jesus. Inventariante: João Pereira Lemos. Ano 1795. Notação 10, caixa 3.636.
} 
escravos do futuro marido! ${ }^{38}$ Mas não basta sabermos que seu casamento foi vantajoso apenas para si própria. Para sabermos que tipo de relação Ana Maria de Jesus manteve com sua família de origem, após seu casamento, e de que forma seus familiares gozaram de uma posição privilegiada frente ao engenho de Sapopemba, vejamos o devir de alguns de seus irmãos.

A primeira, Mariana Joaquina da Soledad, batizava escravos de João Pereira Lemos em 1754. ${ }^{39}$ Casou-se, em 1766, com Mateus Antunes Suzano, cujo pai era afilhado de casamento do pai de João Pereira Lemos. Marianna e Mateus se estabeleceram nas terras compradas pelo capitão João em Campo Grande, na fazenda das Capoeiras (local chamado de Rio da Prata do Pau Picado, que analisaremos a seguir). Outro irmão de Ana Maria, Miguel Cardoso Castel Branco, legou apenas 1.823.697 réis, a serem partilhados entre a viúva e cinco herdeiros, e seus bens imóveis eram apenas uma casa velha. Mas ele possuía duas tarefas de cana em Capoeiras e quatro em Sapopemba. Miguel e outro irmão, Francisco, ambos lavradores de cana, moraram em sítios nas fazendas da irmã e casaram seus filhos com filhos e netos de Ana Maria, seus primos. Suspeitamos que os outros irmãos também tocassem suas vidas em terras contíguas ao engenho de Sapopemba ou do novo engenho das Capoeiras, plantando cana.

No momento de escrever seu testamento, Ana Maria de Jesus se lembrou de quase todos os seus parentes pobres. Seus sobrinhos Luiz e Luiza, filhos da irmã Mariana, que eram seus afilhados, foram mais agraciados que os outros. Francisca, filha de Miguel, também recebeu da tia dinheiro para servir como dote de seu casamento. Ela casou-se com outro sobrinho de Ana Maria, e o novo casal de primos pôde ter casa e partido na fazenda das Capoeiras, propriedade da tia. Para outras duas irmãs, Ana Maria de Jesus deixou pequenos legados em dinheiro.

Ana Maria de Jesus morreu em 1793 e seu irmão Miguel em 1794. Seus inventários refletem a enorme desigualdade econômica que podia reinar no seio de uma mesma fratria. Mas, mesmo tão diferentes economicamente, alguns parentes tiveram ao menos seus sítios e partidos de cana em Sapopemba e Capoeiras ratificados no testamento de Ana Maria. Esses familiares, se não tiveram a sorte de poder herdar o patrimônio de Sapopemba, como a irmã felizarda,

\footnotetext{
${ }^{38}$ ACARJ. AP 343 (1740-1759), folha 51-frente.

${ }^{39}$ ACARJ. AP 343 (1740-1759), folha 92-frente.
} 
tiveram pequenos outros consolos, como dotes, dinheiro, sítios, partidos de cana e esperanças de que suas filhas se casassem com os primos ricos. ${ }^{40}$

Assim, na sombra da pujança do capitão João Pereira Lemos, senhor do engenho de Sapopemba, parece terem vivido quase todos os irmãos, cunhados e sobrinhos de sua esposa, Ana Maria de Jesus, sua prima pobre em terceiro grau. Remotamente aparentados, mas espacialmente vizinhos, alguns lavradores encontraram a maneira certa de fazer convergir os interesses cotidianos - estabilidade, status, terra e trabalho - com a moral da casa: transformaram-se em reserva matrimonial senhorial. Os exemplos nos mostram que eles jogavam com as pontes possíveis de serem trilhadas a partir das alianças com os ramos mais afortunados de sua própria parentela. Afinal, mesmo pobres, eram da família.

Acompanhando os destinos da família de Antônio Cardoso Castel Branco, homem livre senhor de alguns escravos e possivelmente fornecedor de cana para o engenho de Sapopemba, pudemos ver de que forma foram tecidos os vínculos que determinaram sua condição estável de “sitiante” nos domínios da família senhorial dos Pereira Lemos. Os compadrios reforçavam a relação vertical mais próxima daqueles que se avizinhavam no mundo do trabalho. Mas foram os casamentos entre primos, tios e sobrinhos que fizeram efetivamente circular os membros menos afortunados nas terras da família senhorial e, com isso, amalgamavam os destinos de ambos, senhores e lavradores, sobre as mesmas terras. Nossa hipótese é que, para as famílias de lavradores que conseguiram casar seus filhos com os filhos de famílias senhoriais, isso pode ter aberto a possibilidade de sua colocação nos sítios e partidos no interior das fazendas, ou garantido a permanência onde já estavam, caso seus sítios precedessem a chegada dos sesmeiros. Isso porque esses casamentos, criando vínculos entre as duas famílias, possibilitavam a inserção de toda a família do lavrador numa nova rede, mais poderosa, mesmo que numa posição claramente subordinada.

\footnotetext{
${ }^{40}$ No seio dessa família, casaram-se com primos: Ana Maria de Jesus e sua irmã Ana Maria de Oliveira, em 1751; Emerenciana e José Joaquim, herdeiro e senhor da fazenda Tingui, em 1799; Francisca e Luiz Antunes Suzano, em 1797. Cf. ACARJ, AP 287 (1795 a 1804), folhas 60 e 60 verso; RHEINGANTZ, Carlos Grandmasson. Primeiras famílias do Rio de Janeiro. Rio de Janeiro: Livraria Brasiliana, 1965. Para outros exemplos ver PEDROZA, Manoela. Engenhocas da moral: uma leitura sobre a dinâmica agrária tradicional. Tese de doutorado, PPG Ciências Sociais, Unicamp, Campinas, 2008.
} 


\section{Mateus Antunes Suzano e os excluídos senhoriais do Rio da Prata}

Mateus Antunes Suzano era um dos filhos do primeiro sesmeiro de Campo Grande. Ele casou-se com Marianna Joaquina da Soledad em 1766, na capela do engenho de Sapopemba. Mariana, também pobre, era cunhada de João Pereira Lemos, capitão e senhor do engenho de Sapopemba com antigas relações com o pai de Mateus, o que explicaria o casamento dos seus filhos. Mas, nos anos seguintes, Mateus não apareceu nos relatórios como senhor de engenho, como seus irmãos, o que indica o fato de ter sido um excluído senhorial ainda na primeira geração dos Antunes Suzano. Eles se estabeleceram em terras da fazenda das Capoeiras, propriedade da “casa” dos Pereira Lemos. Nesse sítio, Mateus e Marianna tiveram dois filhos, Luiz e Maria Thereza, e depois desapareceram completamente dos nossos registros, o que indica o seu destino de lavradores pobres. Mas, mesmo pobres, eles e seus filhos faziam parte de duas importantes famílias senhoriais locais, e tiveram direito de estabelecer sítios nas terras desses parentes.

Nesse meio tempo, o dono da fazenda das Capoeiras passara a ser um primo do casal, este sim capitão e senhor de engenho: José Antunes Suzano. Seguramente a família de Mateus Antunes Suzano assistiu de perto as peripécias desse primo capitão, sua viuvez, o crescimento de suas crianças, e festejaram seu segundo casamento com Maria Tereza, sua filha e também prima do capitão. Infelizmente, a moça morreu logo e não tiveram filhos. Já Luiz, o outro filho, casou-se com uma prima pobre, Francisca, na capela da fazenda das Capoeiras, em 1797. Pouco antes, Francisca recebera ajuda em dinheiro da tia Ana Maria de Jesus para seu dote. O casal também se estabeleceria dentro da imensa fazenda das Capoeiras, vizinho aos pais de Luiz. ${ }^{41}$

\footnotetext{
${ }^{41}$ RHEINGANTZ, Carlos Grandmasson. Primeiras famílias do Rio de Janeiro. Rio de Janeiro: Livraria Brasiliana, 1965.
} 


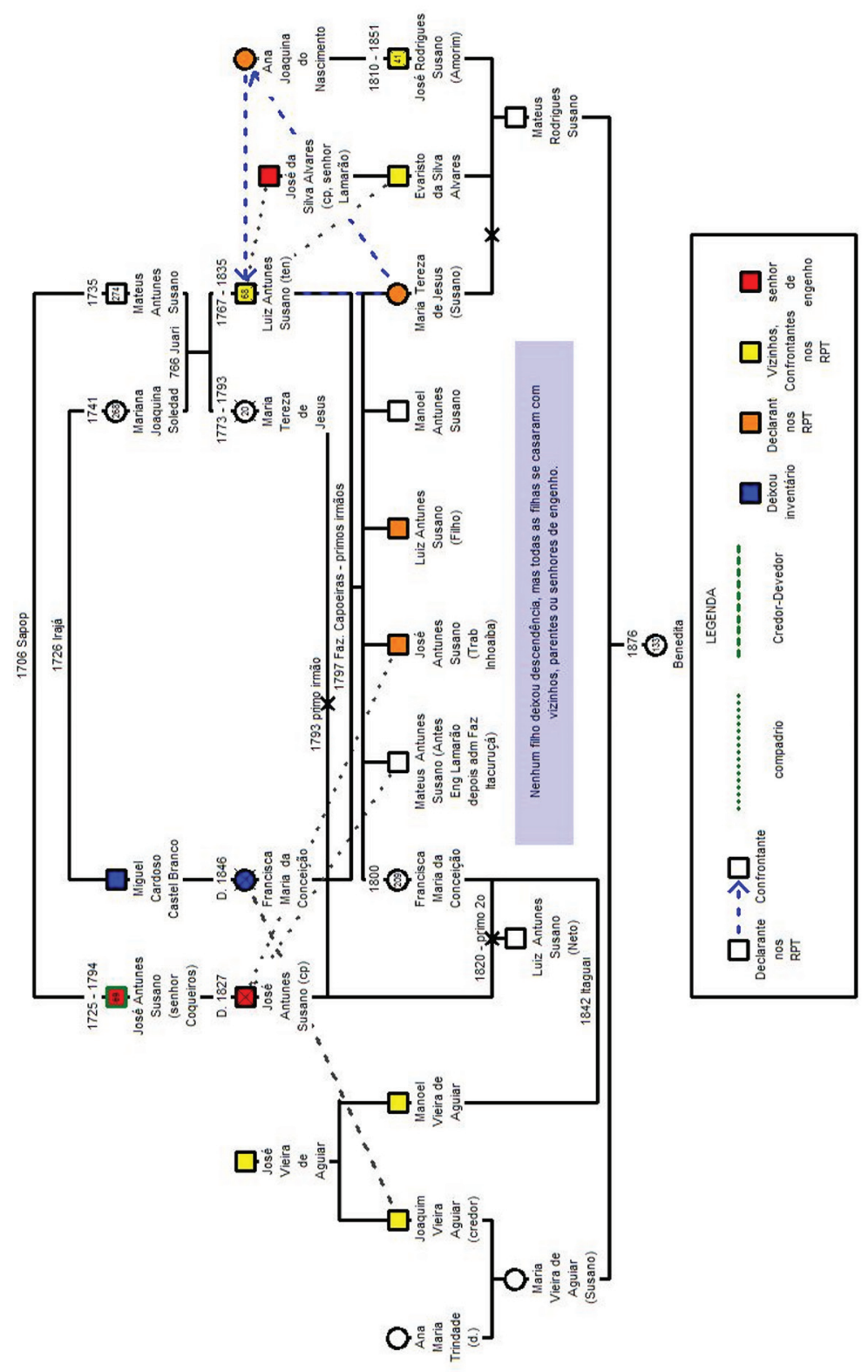

งิ

$\sum_{0}$

告是

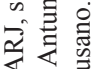

Un w

䒠兽要

in

=

言

के

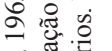

ง



웡

范是国

过

项

तथ

क 0

$\infty$ ?

1 บ

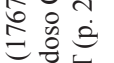

원

可

0 它它

है

워 $\overrightarrow{0}$

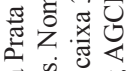

चี லิ

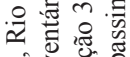

월

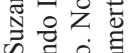

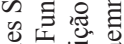
동 至安苍击 命

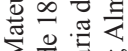

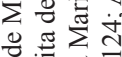
需势

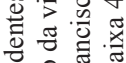
율 올 嘰苛 ด * तै ำ ป त 喽旁产 
Luiz Antunes Suzano chegou a ser tenente, mas não tinha terras, apenas o direito a um pequeno sítio, de 49 braças, dentro da fazenda do primo. Portanto, os seus filhos dependeriam desses contatos para terem acesso à terra de trabalho, se quisessem se estabelecer no local. Em nossa opinião, não por outro motivo o tenente Luiz deu o seu filho mais velho para ser batizado pelo capitão José Antunes Suzano, com o mesmo nome dele. Esse filho sempre trabalhou no engenho de Inhoaíba, como pessoa de confiança do padrinho. Outro filho, Mateus, trabalhava no engenho de Lamarão, vizinho das Capoeiras, até ser convidado pelo tio capitão para administrar outro engenho na distante freguesia de Itacuruçá, para onde se mudou. Morreu solteiro. Uma moça, com bastante sorte, foi escolhida para selar a relação vertical da família pobre de Luiz com o senhor de engenho de Lamarão, casando-se com seu filho. Infelizmente, ela logo ficou viúva, mas seu pai foi testamenteiro do genro falecido e ela teve direito de herdar alguma coisa dos bens do marido, antes de casar-se novamente com outro primo pobre. Do último filho de Luiz Antunes Suzano, Manoel, não temos notícia. ${ }^{42}$

No fim da vida desses primos, tenente Luiz e capitão José, quase como um coroamento por tanta proximidade e fidelidade, o capitão José escolheu como terceira esposa a segunda filha de Luiz, Francisca como a mãe, com a qual teve um filho. Portanto, ao morrer o capitão José Antunes Suzano, em 1827, era sua viúva e inventariante Francisca, filha do tenente Luiz. Além de ele ter dois outros filhos como administradores de engenhos do falecido, era ainda tutor do neto e pai da viúva. Provavelmente por isso o tenente Luiz assumiu total ou em parte a gerência do engenho de Inhoaíba, situação que não agradou aos outros herdeiros, filhos e genros do primeiro e segundo casamentos do capitão José. Eles alegavam que Francisca, filha de Luiz, havia casado com contrato de $\operatorname{arras}^{43}$ e não tinha nenhum direito à meação do espólio. E, ainda, que Luiz e

\footnotetext{
${ }^{42}$ AN. Fundo Inventários. Falecido: José Antunes Suzano. Inventariante: Francisca Maria da Conceição. Notação 39, caixa 3.610.

${ }^{43}$ Dotes e contrato de arras são tipos de contratos pré-nupciais, diferentes da carta de ametade, o regime mais comum de casamento com comunhão de bens. No texto das Ordenações Filipinas consta que "poderá cada hum em o contracto dotal prometter e dar à sua mulher a quantia ou quantidade certa, que quizer, ou certos bens, assí como de raiz, ou certa cousa de sua fazenda, contanto que não passe o tal promettimento, ou doação de arras, da terça parte do que a mulher trouxer em seu dote. (..)” Cf. Ordenações Filipinas, livro 4, título XLVII: Das arras e camera cerrada, fls. 835-837. Para mais detalhes ver MELO, Hildete Pereira e MARQUES, Teresa Cristina Novaes. A partilha da riqueza na ordem patriarcal. Revista de Economia Contemporânea, v. 5, n. 2, 2001, p. 4, nota 15. Para uma análise mais geral do sistema matrimonial no Brasil, ver SILVA, Maria Beatriz Nizza da. Sistema de casamento no Brasil colonial. São Paulo: Edusp, Coleção
} 
seus filhos estavam "arruinando o engenho e a fazenda" de que haviam tomado posse. No calor da disputa pela herança do falecido, sobretudo seus 82 escravos e dois engenhos, os filhos de Luiz foram demitidos pelo genro do capitão.

O fato de ter se estabelecido em sítio nas Capoeiras e ser compadre do capitão José Antunes Suzano abriu portas para os filhos do tenente Luiz, em termos de trabalho, mas nenhum deles deixou descendência conhecida. Provavelmente os quatro homens não se casaram, ou o fizeram fora da freguesia. Também, pudera: em 1835, o pai legaria aos seis herdeiros apenas um sítio de 49 braças de testada no Rio da Prata do Pau Picado (onde morava) e 365.220 réis (59,65 libras) em dívidas a pagar. Como estabelecer mais de uma família em terreno tão pequeno?

A exiguidade de recursos materiais requeria que Luiz pensasse cuidadosamente no casamento de suas duas filhas, já que estas podiam ser "doadas" para outras famílias mais afortunadas. Ele casou cada uma duas vezes, pois ambas ficaram precocemente viúvas. Todos esses quatro matrimônios envolveram vizinhos, fossem filhos de senhores de engenhos (Lamarão e Inhoaíba) ou lavradores (o primo José Rodrigues e os Vieira de Aguiar). Além disso, dois de seus genros eram sobrinho e primo (José Rodrigues e o capitão José Antunes Suzano) e outro genro, além de ter família na propriedade vizinha, era também credor do casal de sogros. ${ }^{44}$

Podemos concluir dizendo que Luiz Antunes Suzano e sua mulher, primos entre si, eram claramente lavradores pobres, o que afetava diretamente as possibilidades de ascensão socioeconômica de sua descendência masculina que devia, por princípio, permanecer e perpetuar o (parco) patrimônio da família de origem.

Coroa Vermelha,1984, sobretudo capítulo VI: O regime de bens. Para uma análise das estratégias matrimoniais da "nobreza da terra” carioca ver FRAGOSO, João Luís Ribeiro. A nobreza da República: notas sobre a formação da primeira elite senhorial do Rio de Janeiro (séculos XVI e XVII). Topoi: Revista de História do Programa de Pós-Graduação em História Social da UFRJ, v. 1, 2000; FRAGOSO, João Luís Ribeiro. A nobreza vive em bandos: a economia política das melhores famílias da terra do Rio de Janeiro (século XVII). Algumas notas de pesquisa. Tempo - Revista do Departamento de História da UFF, v. 8, n. 15, 2003. Para uma avaliação do uso do dote na freguesia de Campo Grande, e de suas diferenças para outros estudos de caso, ver PEDROZA, Manoela. Engenhocas da moral: uma leitura sobre a dinâmica agrária tradicional. Tese de doutorado, PPG Ciências Sociais, Unicamp, Campinas, 2008.

${ }^{44}$ A viúva Francisca Maria da Conceição (mãe) declarou, no inventário do marido, que o casal possuía dívidas ativas para com Joaquim Vieira de Aguiar. Esse Joaquim era irmão de Manoel Vieira de Aguiar, que se casaria com a filha de Francisca em 1842. As duas famílias - Antunes Suzano e Vieira de Aguiar - foram confrontantes reconhecidos no registro paroquial de terras, em 1854. Cf. AN. Fundo Inventários. Nome: Luiz Antunes Suzano. Ano 1835. Notação 5.261, caixa 4.124; AN. Fundo Inventários. Falecido: José Antunes Suzano. Inventariante: Francisca Maria da Conceição (filha). Notação 39, caixa 3.610; e AGCRJ. 68-3-75, 4º volume. 
Mesmo assim, eles se aproveitaram de relações vicinais antigas e bem consolidadas, do status de suas famílias extensas e de pontes parentais que lhes permitissem catapultar as filhas por horizontes mais amplos que os de seus pais e irmãos.

Como regra geral, todos os sitiantes tentavam casar seus filhos com vizinhos, espalhando as filhas pobres pelos arredores ou recebendo noras também pobres em seus pequenos sítios. Mas os sitiantes excluídos senhoriais tinham um trunfo a mais para suas estratégias: o pertencimento à parentela senhorial. O fato de ter doado suas filhas para senhores vizinhos, além da ascensão social de ambas, também abriu a Luiz outras possibilidades, em termos de status local. Por esse meio ele foi sogro e testamenteiro do filho do senhor do engenho de Lamarão, e sogro e tutor do filho do senhor de Inhoaíba, seu primo. Status que, como vimos, não agradava à parte rica da família Antunes Suzano, e gerou atritos no fim de sua vida.

A trajetória de Mateus Antunes Suzano e sua descendência, sitiantes no Rio da Prata do Pau Picado, nos remete à desigualdade econômica dos excluídos senhoriais, atenuada, ou mascarada, pela proximidade com seus parentes ricos. Como vimos, Mateus, excluído dos Antunes Suzano, havia se estabelecido em terras do capitão João Pereira Lemos graças ao casamento com a cunhada daquele. Seus filhos, tenente Luiz e Maria Tereza, dependeriam das benesses de outro primo capitão, José Antunes Suzano, para conseguirem terra, trabalho e bons casamentos. O tenente Luiz conseguiu se relacionar mais proximamente com o primo capitão, beneficiando a si e aos filhos com essa proximidade. Como se percebe, a desigualdade se reproduzia de uma geração para a outra, através da herança preferencial, mas ela também era instrumentalizada pelos próprios excluídos.

\section{Anna Joaquina do Nascimento e suas artimanhas}

Anna Joaquina do Nascimento, que se apresentava como outra irmã do tenente Luiz Antunes Suzano, se casaria com Manoel Rodrigues de Amorim, um “joão-ninguém local”, ou um sem terra de longa data. ${ }^{45} \mathrm{O}$ casal também se

\footnotetext{
${ }^{45}$ Anna Joaquina do Nascimento foi casada com Manoel Rodrigues de Amorim. O pai do seu marido, Silvestre Rodrigues, teria emigrado de Angra dos Reis, casado em Campo Grande, onde trabalhava nas fazendas da região e batizava filhos de escravas na década de 1750. Essa informação consta num dos registros de batismo em que foi padrinho. Cf. ACARJ. Livro de registro de batismos de livres, Freguesia de Campo Grande (1752 a 1759). Folha 124-verso.
} 
estabeleceria num sítio em Rio da Prata do Pau Picado, na franja da fazenda das Capoeiras. Mas, para abalar sua relativa tranquilidade, por volta de 1794, chegou à vizinhança um novo dono para o engenho de Juari, Bernardo José Dantas, que se tornaria vizinho deles pelo lado oposto ao da sede da fazenda das Capoeiras. Dantas, ao comprar esse engenho (entre 1777 e 1793) tentou se afirmar como proprietário das terras em questão, para auferir renda. Uma das famílias pressionadas foi a de Anna Joaquina. Não por acaso, pela declaração de Dantas, o sítio de Anna Joaquina foi recenseado, em 1813, como estando dentro das terras da fazenda de Juari. ${ }^{46}$

Na época, o casal se negou a estabelecer essa relação de subordinação a Dantas. O processo foi parar no Tribunal da Relação, onde várias testemunhas foram ouvidas para atestar a posse "mansa e pacífica" de Anna Joaquina e Manoel sobre o sítio e, mesmo sem os supostos parentes depondo a seu favor, Anna Joaquina repetiu diversas vezes que recebera a terra de seu pai, Matheus Antunes Suzano. Enquanto isso, Dantas não conseguia provar, pelos títulos, serem suas as terras onde vivia a família de Anna Joaquina.

Então, em 1820, os litigantes assinaram um acordo que, quando se procedesse à medição regular, Anna se comprometeria a pagar um arrendamento anual a Dantas, caso o terreno lhe pertencesse. Essa medição nunca aconteceu, e os herdeiros de Anna Joaquina declarariam possuir esse mesmo sítio, em 1856, e morariam na região até $1889 .{ }^{47}$ Portanto, na contenda entre Bernardo José Dantas, senhor de engenho, com Anna Joaquina, sitiante, a prova dos títulos não beneficiou o senhor recém-chegado. A partir de 1838, ela conseguiu passar integralmente esse sítio ao filho José Rodrigues, que lá se estabeleceria casado com uma prima. Seu outro filho, Luiz Rodrigues, parece ter conseguido se casar com moça do clã Coelho da Silva, vizinhos e novos proprietários da fazenda de Juari. Mas as seis filhas de Anna Joaquina, depois de casarem-se com desconhecidos e batizarem os primeiros filhos, desapareceram de nossos registros, indicando seu destino apagado ou a emigração.

Anna Joaquina não declarou a sua própria filiação, nem a cadeia dominial do seu sítio, em nenhum momento no longo inventário do seu marido nem nos inúmeros processos que sustentou para manter suas terras, contra seus vizi-

\footnotetext{
${ }^{46}$ FRÓES, Jose Nazareth de Sousa e GELABERT, Odaléa Ranauro Ensenat. Rumo ao Campo Grande: por trilhas e caminhos. Rio de Janeiro: sem editora, 2004.

${ }^{47}$ AN. Fundo SDJ Processos diversos. Local: Campo Grande. Antônio José Coelho da Silva e seus filhos, apelante. Apelação cível número 430, caixa 26. ano 1833, fl. 4.
} 
nhos. Também não encontramos nenhum suposto familiar como testemunha. Depois de muito buscar, encontramos a primeira automenção à sua filiação nos registros de batismo de duas filhas (de 1811 e 1819), mas sabemos o quanto essa autodeclaração pode ser enganosa, já que não se requeria comprovação. Por isso, ficamos com a impressão de que ela se valeu menos das relações com a parentela rica e não cimentou alianças através do casamento das filhas com primos. Mas, no correr de nossa pesquisa, descobrimos o porquê.

Chegamos à conclusão que Anna Joaquina do Nascimento não era filha de Mateus Antunes Suzano. Ela alegou o pertencimento a essa casa durante quase quarenta anos e, pela repetição, quase nos convenceu. Mas recolhemos inúmeros indícios em contrário. Primeiro, o cuidadoso genealogista Carlos Rheigantz, que sistematizou todos os registros de batismo, casamento e óbito, e não a listou como filha de seus pais. ${ }^{48}$ Depois, em 1793, Ana Maria de Jesus, meeira do engenho de Sapopemba, sua suposta tia, legou dinheiro para várias sobrinhas terem seus dotes, citou textualmente Mateus Antunes Suzano como seu compadre... e não se referiu a nenhuma Anna Joaquina.

Mas nossa evidência mais contundente foi o comportamento matrimonial de Anna Joaquina e sua família ter sido completamente diferente dos membros de sua suposta família. Como vimos, a família de Mateus Antunes Suzano e Mariana Joaquina da Soledad, excluídos senhoriais, foi reserva matrimonial constante para o ramo mais afortunado dos Antunes Suzano, e ambos tinham fortes e antigos vínculos de vizinhança, de compadrio, de trabalho e matrimoniais, tanto com o engenho de Sapopemba quanto com o de Capoeiras. Os filhos de Mateus e Mariana (Luiz e Maria Tereza, segundo Rheigantz) casaramse com primos dessa parentela, ricos ou pobres. Seus netos (os seis filhos de Luiz) permaneceram intimamente vinculados ao capitão José Antunes Suzano, senhor das Capoeiras, como afilhados, administradores, fornecedores de cana, vizinhos, tutores, até cônjuges. Dentro desse contexto, seria novamente muita coincidência que Anna Joaquina e sua descendência fossem os únicos que não partilhassem dessas práticas!

Concluímos que Anna Joaquina foi muito esperta. ${ }^{49}$ Provavelmente nascida e criada no Rio da Prata do Pau Picado, nas imediações do engenho de Juari,

\footnotetext{
${ }^{48}$ Notamos que toda sua suposta família foi registrada por Rheigantz: avós, pais, irmãos, primos, inclusive com seus cônjuges e descendência. Cf. RHEINGANTZ, Carlos Grandmasson. Primeiras famílias do Rio de Janeiro. Rio de Janeiro: Livraria Brasiliana, 1965, tomo II, p. 107 a 111.

${ }^{49}$ Agradecemos à professora Silvia Hunold Lara, que foi a primeira a usar precisamente esse ad-
} 


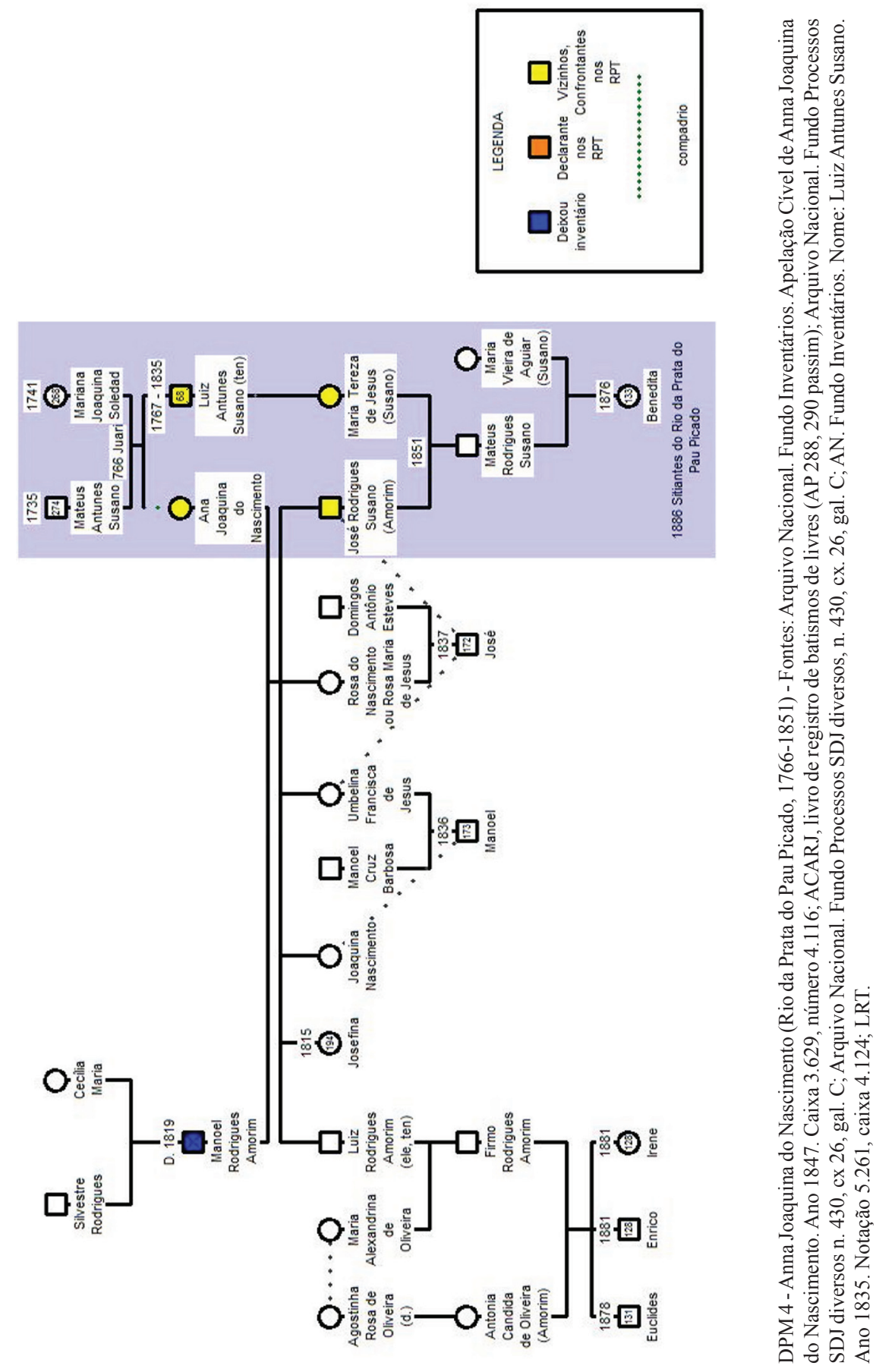


quem sabe vizinha, afilhada, filha ilegítima ou mesmo criada por Mateus Antunes Suzano e Marianna (já que o pároco em 1813 a listou como Anna Joaquina da Soledad, ${ }^{50}$ sobrenome de Marianna), ela defendeu o que considerava seu direito (a posse do sítio) lançando mão estrategicamente de um princípio forte da ordenação do mundo em que vivia, para produzir efeitos simbólicos no momento de dificuldade por que passava. Alegando a qualidade de herdeira de um excluído senhorial, ela subia alguns degraus na escala dos direitos locais, e como que se imunizava das investidas de um senhor desconhecedor das estirpes da vizinhança.

Portanto, para entender a vitória de Anna Joaquina é preciso entender a fonte de legitimidade dos direitos que ela declarou ter sobre aquele sítio. Seguramente ela podia ter litigado em outros termos: podia ter tentado provar sua posse "mansa e pacífica", ter migrado, ter buscado um padrinho ou ter aceitado a condição de arrendatária, mas preferiu usar um argumento moralmente mais poderoso: o pertencimento à casa senhorial dos Antunes Suzano. Se a resposta de Anna Joaquina parece curiosa, ou mentirosa, para o nosso olhar desacostumado, não o foi para essa moral, pois que ela manteve a posse autônoma sobre o sítio do Rio da Prata do Pau Picado e o legou ao seu filho. Sem entrarmos em divagações moralistas, sua declaração surtiu efeitos de verdade.

\section{Quem eram e para que serviam os excluídos senhoriais}

Em outro trabalho comprovamos que, via de regra, as primeiras famílias colonizadoras de Campo Grande, no início do século XVIII, formaram-se através de “casamentos desiguais” entre moças pobres do local e portugueses mais afortunados. ${ }^{51}$ Mas com o desenrolar das gerações, a meação entre os casais e a herança desigual, a diferença econômica inicial perderia esse contraste marcado, assumindo vários matizes no interior da mesma família e do mesmo território. Para começar a entender essa construção histórica, não podemos desconsiderar que os engenhos tinham fome de cana e dependiam dos vários partidos dos lavradores para alimentar a sua fábrica. Essa dependência e a proximidade

jetivo, ao conhecer partes da trajetória de Anna Joaquina. Graças a suas indicações, perseguimos essas pistas e reunimos o conjunto de indicações que agora expomos ao leitor.

${ }^{50}$ FRÓES, Jose Nazareth de Sousa e GELABERT, Odaléa Ranauro Ensenat. Rumo ao Campo Grande: por trilhas e caminhos. Rio de Janeiro: sem editora, 2004, p. 101 a 115.

${ }^{51}$ PEDROZA, Manoela. Engenhocas da moral: uma leitura sobre a dinâmica agrária tradicional. Tese de doutorado, PPG Ciências Sociais, Unicamp, Campinas, 2008. 
espacial entre as famílias dos senhores e dos seus fornecedores consolidariam relações mais próximas entre lavradores e senhores de um mesmo engenho, refletidas nos batizados entre seus plantéis e mesmo entre si.

Mas não podemos ver essa relação apenas nos termos econômicos, do fornecimento da cana e de mão-de-obra. Os vínculos entre senhores e lavradores devem ser encarados também como lances estratégicos dos mais pobres, a fim de que não se perca a dimensão negociada e voluntária dessas redes. Nesses termos, um degrau acima dos lavradores anônimos, encontramos aqueles que puderam ser compadres dos senhores, o que já era alguma coisa a mais. Poucos o conseguiram de maneira isolada, a partir de seu status individual. ${ }^{52} \mathrm{Na}$ maior parte das vezes, esse vínculo exigia uma ponte anterior: lavradores pobres davam seus filhos para serem batizados pelo senhor quase sempre depois que uma mulher aparentada fosse “doada” àquela família senhorial num "casamento desigual". Assim fizeram os pais e irmãos pobres de Ana Maria de Jesus, meeira de Sapopemba; e a família de Mateus Antunes Suzano, compadres, cunhados e primos dos senhores do engenho das Capoeiras. ${ }^{53}$ Podemos perceber que, iniciando em tímidos compadrios, essas relações, com sorte, poderiam se desdobrar em confiança mútua, pela qual os lavradores saíam de seus arrendamentos, partidos e sítios e galgavam postos na gerência ou mesmo na administração direta do patrimônio senhorial.

Mas não apenas de compadrios se faziam as relações sociais locais, algo que, grosseiramente falando, apenas perpetuaria relações verticais entre senhores e lavradores vizinhos. Não podemos esquecer que as famílias senhoriais da época transmitiam seu patrimônio através dos mecanismos da sucessão preferencial, ou seja, passando os principais bens de raiz para um único filho. Tratava-se de uma seleção do pai entre seus filhos, e depois, entre os filhos dos filhos. Portanto,

\footnotetext{
${ }^{52}$ Como o padre Francisco Nunes de Souza, de família vizinha e cliente de Sapopemba, que batizou dois filhos do capitão João Pereira Lemos. Cf. RHEINGANTZ, Carlos Grandmasson. Primeiras famílias do Rio de Janeiro. Rio de Janeiro: Livraria Brasiliana, 1965, tomo II, p. 107 a 114; e ACARJ. Livro de registro de batismos de livres, freguesia de Campo Grande (1752 a 1759), p. 59-frente; Livro de registro de batismos de escravos, freguesia de Irajá (AP 343), folhas 52-frente, 27-verso, 80-verso, 89-verso, 107-verso, 105-frente; e Livro de batismo de livres, fls 94-frente e 106-frente.

${ }^{53}$ Na fazenda do Viegas, Manoel Coelho Borges foi administrador por vários anos, chegando a ser tutor dos filhos do falecido casal de senhores, compadres e primos distantes. Redes parentais envolvendo os lavradores vizinhos aos engenhos de Campo Grande foram mais bem analisadas em PEDROZA, Manoela. Engenhocas da moral: uma leitura sobre a dinâmica agrária tradicional. Tese de doutorado, PPG Ciências Sociais, Unicamp, Campinas, 2008.
} 
mesmo no seio de uma rica família, por exemplo, de um sesmeiro e senhor de engenho, a cada geração se recriava um terceiro escalão, que chamaremos de excluídos senhoriais, isto é, filhos que pertenciam a famílias senhoriais, mas que, pela cultura da herança desigual, não recebiam bens de raízes no momento da partilha. Ou seja, eram filhos de senhores que não reproduziam a condição senhorial dos pais, nem como sucessores de seus engenhos, nem ao menos como herdeiros de glebas da família. ${ }^{54}$

A partir da necessidade de ao menos garantir a sobrevivência das famílias desses filhos sem herança, a estratégia senhorial corrente consistia em instalá-los em sítios dentro das terras da família ou de outras famílias senhoriais amigas. Que vantagens esses sítios trariam para o mundo concreto da sobrevivência cotidiana? Primeiro, o sítio não afastava completamente o "terceiro escalão" do usufruto das terras da família, ou seja, não os condenava à exclusão total, emigração ou celibato. Além de terem terra suficiente para alimentar a família, poderiam abrir outras posses mais distantes e ter outros partidos. Em outras palavras, eles não seriam obrigados a deixar a casa, nem a fazenda em que nasceram, nem a permanecer solteiros como empregados do irmão sucessor. Por último, o sítio ao lado do engenho mantinha sob o mesmo manto da 'casa' parentes de desiguais estatutos, uma forma de garantir a qualidade desta casa, em detrimento das desigualdades econômicas em seu interior.

Socialmente, os excluídos senhoriais que se tornavam sitiantes não sofriam constrangimentos para escolha do cônjuge, buscado entre os lavradores pobres vizinhos. Plenamente inseridos nas estratégias matrimoniais mais amplas de suas famílias, seus casamentos, mesmo que não envolvessem patrimônio expressivo, não se davam em qualquer direção, obedecendo aos fluxos de trocas de mulheres entre famílias aparentadas ou aliadas. Essa rede de parentela, por sua vez, era ampla e complexa e, quando se tratava de casar um excluído, lançava mão principalmente de membros também excluídos ou mais distantes do núcleo principal, como cunhados, primos, sobrinhos que podiam provir de ramos pobres da parentela ou mesmo de ramos nada senhoriais de lavradores locais.

\footnotetext{
${ }^{54}$ Aqui, usamos a mesma definição de "excluído da herança” de Sylvie Dépatie e John Dickinson. Ver DICKINSON, John. Destins familiaux dans de gouvernement de Montréal sous le régime français: les Brunet. In: BOUCHARD, G. et al (ed.). Les exclus de la terre en France et au Québec XVIIe-XXe siècles. La reproduction familiale dans la différence. Sillery: Septentrion, 1998; DÉPATIE, Sylvie. La transmission du patrimoine au Canada (XVIIe -XVIIIe siècle): qui sont les défavorisés? RHAF: Revue d'Histoire de l'Amérique Française, v. 54, n. 4, 2001, p. 558-570.
} 
Mas, eram sempre vizinhos, aliados ou clientes do senhor. Assim, amarrando entre si famílias senhoriais e de pobres, os excluídos teciam as redes parentais, vicinais e matrimoniais da freguesia.

Depois de casados, o casal de excluídos que se tornava sitiante não era alijado do circuito familiar, da casa-grande nem da vizinhança. Ainda por cima, podia usar o nome da família para ocasiões em que o prestígio, e não os recursos econômicos, fosse a moeda de troca principal, como nos batizados e nos testemunhos em processos. Via de regra, no momento do testamento, os primos pobres eram lembrados pelos generosos senhores, receberiam legados para seus dotes, sítios onde morar, quem sabe trabalho e terras também para os seus filhos casados. Na mais absoluta sorte, os excluídos veriam seus filhos casar-se com os primos ricos. Nesse caso, não se tornariam um deles, porque já o eram, mas seriam alçados ao circuito mais amplo de direitos sobre o patrimônio familiar (como tutores, inventariantes ou herdeiros colaterais), de que haviam sido anteriormente alijados.

Por último, juridicamente, esses sitiantes excluídos senhoriais tinham o direito de usus, frutus, e apenas não o de abusus sobre esses sítios, que cabia ao herdeiro preferencial. Mas eles poderiam sempre alimentar a esperança, bastante confirmada pelos casos que estudamos, de que seus filhos seriam a reserva matrimonial preferida dos tios e primos mais ricos, criando, com isso, um circuito matrimonial que repunha, para alguns filhos, as condições econômicas perdidas pelos pais. Por isso, esses irmãos ou primos pobres carregariam com orgulho o nome da família.

Devemos lembrar aqui que lidamos com uma sociedade de valores corporativos naturalizados. Nesse contexto, parecia natural que os indivíduos não fossem iguais e que não tivessem os mesmos direitos. Pelo contrário, a moral da época zelava para que cada um vivesse “conforme a sua lei”, como pedaços separados que compunham, com suas diferentes qualidades, o corpo social mais amplo. ${ }^{55}$ Sendo assim, nada mais natural que ao sucessor do senhor fosse dado o direito

\footnotetext{
${ }^{55}$ Segundo a moral corporativa da época, cada corpus da sociedade tinha sua qualidade, algo como status, que devia ser preservada por um padrão de vida material e por uma conduta moral condizentes. Segundo Hespanha, uma qualidade conferia um estatuto que "comportava certos direitos, mas também certos deveres. E, sobretudo, uma obrigação de assumir em tudo uma atitude social correspondente ao estado, atitude que a teoria moral da época definia como 'honra'.” HESPANHA, António Manuel e XAVIER, Ângela Barreto. A representação da sociedade e do poder. In: HESPANHA, António Manuel. O Antigo Regime. Lisboa: Estampa, 2006.
} 
de herdar o engenho, aos outros filhos porções menores da herança, e a alguns nada, ou quase nada. Longe de uma igualdade legal ou de fato, todos sabiam que possuíam qualidades, status e posições sociais muito distintas a zelar.

Mesmo pertencendo ao ramo excluído senhorial dos Antunes Suzano de longa data, os descendentes de Mateus Antunes Suzano se sentiam plenamente no direito sobre seus pequenos sítios. Embora essa herança legalmente não existisse na forma de títulos, nem pudesse ser reconhecida como posse em área devoluta, foi tacitamente registrada e reconhecida por confrontantes no momento dos registros paroquiais de terras, entre 1854 e 1856. Nesse momento, os sítios dos herdeiros de Luiz Antunes Suzano e de Anna Joaquina do Nascimento foram registrados sob diversas rubricas: datas, situações, posses. A clareza com que estes e outros sitiantes declararam áreas, forma de aquisição e confrontantes formalmente não os diferiria de pequenos proprietários locais, embora legalmente fossem, no máximo, posseiros. ${ }^{56}$

Assim, os sitiantes nas terras de seus irmãos mais sortudos perpetuavam uma teia de reciprocidades entre desiguais que deve ter conferido legitimidade e estabilidade a um contexto social e economicamente hierarquizado. Os excluídos senhoriais eram o resultado da mediação entre desigualdade econômica, desigualdade de direitos sobre as terras, de uma moral familiar particular e das diversas possibilidades de ascensão ou queda de status social, naquele contexto. ${ }^{57}$

Em nossa opinião, a dúvida sobre o estatuto jurídico dos sitiantes pode ser dirimida apenas sob a luz de uma dinâmica agrária pautada numa moral particular, e não através do debate jurídico sobre posses e propriedades. Em outras palavras, a forma com que sitiantes encararam suas terras nos registros paroquiais não pode se explicar apenas em termos econômicos - se eram ricos ou pobres, lavradores ou fazendeiros - nem em termos estritamente legais - pois também não eram nem proprietários titulados, nem posseiros independentes nem tampouco pela busca minuciosa dos termos nativos e suas nuances, nos métodos de uma descrição densa.

Devemos deixar claro que, no caso dos sítios, não podemos falar em pequenas propriedades herdadas em torno (isto é, fora) de uma área determinada,

\footnotetext{
${ }^{56}$ AGCRJ. 68-3-75, 4${ }^{\circ}$ volume.

${ }^{57}$ Para uma análise da “mobilidade social” no Antigo Regime, ver LEVI, Giovanni. Carrières d'artisans et marché du travail à Turin (XVIII-XIX siècles). Annales ESC, v. ano 45, n. 6, 1990, p. 1.351-1.402. E HESPANHA, António Manuel. A mobilidade social na sociedade de Antigo Regime. In: Tempo, v. 11, n. 21, 2006, p. 121-143.
} 
como uma fazenda. Como vimos, tratavam-se de sítios não titulados, não de propriedades formais. Mas eles passavam de pai para filho não como posses autônomas (que se tornavam propriedade, pela lei), ${ }^{58}$ e sim como direito que emana do vínculo com uma família senhorial, legitimados pela moral local que, nos testamentos, apareciam maquiados como legados, favores ou benesses concedidos pelo senhor das terras, que era quase sempre um compadre ou aparentado das famílias sitiantes.

Ao menos na freguesia de Campo Grande, poucas terras não impediam que excluídos senhoriais partilhassem de uma porção do status, do patrimônio e até da autoridade de sua família. Status, aliás, que pode ser entendido como legitimidade social mais ampla, pois esses sítios só conseguiram se estabelecer ou se manter em terras sob jurisdição alheia, na condição mais favorável do que a de meros agregados, não porque tivessem títulos, mas porque eram respeitados e reconhecidos pela comunidade do seu entorno. Ou seja, esses sitiantes eram nós por vezes estratégicos das tramas locais, e faziam parte dos circuitos parentais e patrimoniais mais amplos, sobretudo via casamentos e compadrios. Sendo assim, os vínculos parentais ligavam todos à mesma "casa” e não os congelavam em pontos separados da estrutura social, cujos polos espacialmente marcados seriam a casa-grande com seu engenho e as bibocas dos sitiantes, com suas roças.

Enquanto universo moral partilhado, essa lógica familiar corporativa não dependia de títulos e de cercas para se afirmar, já que não lidava com propriedades privadas e direitos exclusivos no sentido moderno. ${ }^{59}$ Nossa hipótese é que os sítios faziam parte de um mesmo pacote de direitos de propriedade sítios-engenho-plantações-matas-rios - adquiridos no momento em que uma sesmaria territorialmente imprecisa foi concedida a uma família senhorial. Esse conjunto de recursos era acessível a outras famílias, desde que pertencentes à mesma rede de parentela senhorial e segundo uma hierarquia de direitos de propriedade e de uso que marcava a desigualdade socioeconômica entre seus

\footnotetext{
${ }^{58}$ Sobre a transformação da posse em propriedade ver estudo de Márcia Motta in LARA, Silvia Hunold e MENDONÇA, Joseli Maria Nunes (orgs). Direitos e justiça no Brasil: ensaios de história social. Campinas: Unicamp, 2006.

${ }^{59}$ Sobre o processo histórico de construção da propriedade privada no mundo moderno, ver CONGOST, Rosa. Tierras, leyes, historia: estudios sobre 'la gran obra de la propriedad'. Barcelona: Critica, 2007. Para o caso brasileiro ver VARELA, Laura Beck. Das sesmarias à propriedade moderna: um estudo de história do direito brasileiro. Rio de Janeiro: Renovar, 2005.
} 
membros. Seguindo esses preceitos, os sítios eram encarados localmente como herança familiar aos seus membros menos sortudos. Portanto, defendemos que, no momento dos registros paroquiais de terras, os sitiantes declararam direitos, plenamente legitimados pela “economia moral”60 local, e não propriedades, nem posses, segundo o código jurídico formal.

\section{Conclusão}

Neste trabalho, partimos da premissa de que as condições físicas e econômicas (como abundância de terras, qualidade do solo, clima, produção agrícola, entre outros) não devem ser vistas como determinantes mecânicos da estrutura fundiária de uma região, e que esta tem uma história que não é apenas construída pelos códigos legais, mas pela ação microscópica dos sujeitos que a viveram. Acreditamos que os homens e mulheres puderam, a partir de sua cultura, estratégias e possibilidades, tecer seu futuro e, com ele, sua paisagem. Portanto, nossa lupa perscrutou família por família para, a partir de casos concretos, extrairmos os elementos explicativos da estrutura sesmaria-engenho-sítio. Julgamos que as trajetórias dos excluídos senhoriais dos Antunes Suzano e dos Castel-BrancoPereira Lemos confluem para confirmar as hipóteses que defendemos, acerca das consequências das estratégias patrimoniais e familiares na configuração territorial da freguesia.

Internamente, a parentela senhorial, extremamente diferenciada social e economicamente, parecia concordar em ter direitos diversos sobre o patrimônio. Mas, mesmo inseridas na cultura senhorial da época, as famílias senhoriais de Campo Grande puderam agir com outros recursos para atenuar as dificuldades vividas por seus setores excluídos da herança. A baixa densidade demográfica, a existência de terras livres e pouca pressão dos engenhos sobre seu entorno possibilitaram uma solução original para o problema da transmissão fundiária.

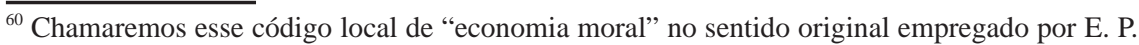
Thompson, já que orientava as ações de todo o corpo social e submetia os interesses puramente econômicos e oportunidades individuais no curto prazo aos interesses da "casa”, às soluções de compromisso, ao equilíbrio entre desiguais, a salvaguardar posições, exigências sociais e compromissos selados. Cf. THOMPSON, Edward Palmer. Costumes em comum. São Paulo: Companhia das Letras, 1998. Aliás, algo comum na dinâmica de sociedades não capitalistas. Cf. , p. 62. Para uma melhor discussão dessa “economia moral” local, ver PEDROZA, Manoela. A economia moral de uma dinâmica agrária de tipo tradicional: um estudo sobre a manutenção de reciprocidades desiguais em terras comuns (freguesia de Campo Grande, Rio de Janeiro, século XIX). Mana: Revista do Programa de Antropologia Social da UFRJ, em avaliação.
} 
Os pais legavam seu patrimônio conforme uma hierarquia de direitos que começava no grau máximo, de sucessor do engenho e dos títulos do pai, passava por algumas gradações, como herdeiros de porções menores ou móveis do patrimônio, pelas filhas que recebiam dotes, até chegar aos filhos quase sem direitos de herança que tinham apenas direito de usar um pedacinho da grande sesmaria ociosa da família, a quem chamamos de excluídos senhoriais.

Para o bem da "casa” se construíra um sistema em que a exclusão social (expropriação) não era absoluta, e tinha legitimidade na moral da época. Pelo lado da "ideologia", ${ }^{61}$ os filhos de terceiro escalão das famílias de proprietários que permaneciam como sitiantes nas terras de seus irmãos mais sortudos criavam uma situação que pode, a nosso ver, conferir legitimidade e estabilidade a um contexto de grandes desigualdades econômicas. O sítio dentro da sesmaria e ao lado do engenho encobria a exclusão da maioria dos filhos ao direito de herança, mantendo-os sob o mesmo manto da "casa”, de sua qualidade e seu estatuto.

Portanto, os sitiantes eram, basicamente, famílias formadas pelos excluídos senhoriais, seus parceiros e seus descendentes. Além disso, os compadrios intraparentela podem nos dar uma pista dos mecanismos que reforçavam, no tempo, os vínculos entre irmãos senhores e irmãos sitiantes, uma forma de manter a casa coesa e seus membros próximos, em detrimento das desigualdades econômicas em seu interior.

Em seguida, vimos que, externamente, diante da comunidade, reconhecia-se o pertencimento desse “terceiro escalão” à parentela senhorial, o direito maior do sesmeiro sobre as terras em que se moviam os vários extratos de sua parentela, mas também os direitos dos excluídos aos seus sítios. Posse e propriedade não se opunham de forma tão clara, já que os sitiantes não foram destituídos facilmente, mesmo por proprietários titulados.

\footnotetext{
61 "Enquanto os homens, por força de seu modo material de atividade, são incapazes de resolver essas contradições na prática, tendem a projetá-las nas formas ideológicas de consciência, isto é, em soluções puramente espirituais ou discursivas que ocultam efetivamente, ou disfarçam, a existência e o caráter dessas contradições. Ocultando-as, a distorção ideológica contribui para a sua reprodução e, portanto, serve aos interesses da classe dominante. (..) A ideologia, portanto, conserva sempre sua conotação crítica e negativa, mas o conceito só se aplica às distorções relacionadas com o ocultamento de uma realidade contraditória e invertida. Nesse sentido, a definição tão frequente de ideologia como falsa consciência não é adequada na medida em que não especifica o tipo de distorção criticada (..)” Cf. BOTTOMORE, Tom (ed). Dicionário do pensamento marxista. Rio de Janeiro: Jorge Zahar Editor, 1988, verbete "ideologia", p. 185.
} 
Também vimos que foi por meio de alianças parentais que as famílias senhoriais se relacionaram com as de lavradores vizinhos, mas que essas relações comportavam resultados distintos. Por um lado, o batismo codificado selava a subordinação desses homens livres, que também pode ser comprovada por outros elementos, como, por exemplo, o fato de serem fornecedores de cana e devedores do mesmo senhor. O elemento que gostaríamos de ressaltar é que, ao menos até aquela época, essa subordinação não parecia ser devida apenas ao fato de "morarem” em "propriedade” do senhor, ou seja, de não serem proprietários autônomos de seus terrenos. Num momento em que a propriedade privada da terra não estava dada nem nos códigos legais e nem na cultura senhorial, a subordinação política e econômica do que poderia ser chamado de "campesinato" no Brasil parecia se construir por outros meios que não o monopólio da propriedade da terra.

Mas essa subordinação não era estanque nem monolítica, fixando eternamente em lados separados da estrutura social esses dois grupos de homens livres. As famílias de lavradores que, acionando um elemento forte da moral da época, qual seja, a identidade parental, conseguiram casar seus filhos com os excluídos senhoriais, tiveram a possibilidade de estabelecer sítios no interior dos domínios senhoriais. Mais do que isso, via “casamentos desiguais”, algumas filhas de lavradores se tornaram matriarcas de clãs senhoriais, meeiras dos bens do capitão local. E filhos de sitiantes que eram afilhados de senhores puderam ter acesso a cargos de direção ou administração dos engenhos, galgando degraus de ascensão econômica dentro das possibilidades concretas a eles fornecidas.

Por fim, mas não menos importante, defendo que os excluídos senhoriais eram mais do que apenas filhos excluídos da propriedade da terra: eram pontes entre o mundo dos senhores e dos lavradores, além de corporificarem práticas culturais e morais e uma hierarquia de acesso aos recursos naturais locais únicos que pretendi analisar no artigo. Usando-os como lente explicativa, o que vimos esboçado na Desobriga de 1813 foi um mosaico de sítios, datas, partidos, engenhos, fazendas, situações e sesmarias, de diversos tamanhos, capacidades produtivas e histórias. Remontando um pouco às redes de passado dos indivíduos citados nessa listagem, pudemos notar que aquela estrutura fundiária sui generis era a marca territorial de antigas estratégias de aliança entre famílias, de destinos diferenciados da parentela senhorial, de possibilidades de acumulação e dos direitos desiguais historicamente construídos por seus membros. Mas como se poderia sustentar um sistema de transmissão tão complexo e diferenciado se a legis- 
lação previa formas de acesso e posse das terras bastante diferentes das soluções encontradas em nível local? Essa já é outra história, assunto para outro trabalho. ${ }^{62}$

\section{Referências bibliográficas}

ABREU, Antonio Izaías da Costa. Municípios e topônimos fluminenses: histórico e memória. Niterói: Imprensa Official do Estado do Rio de Janeiro, 1994.

AUGUSTINS, Georges. Esquisse d'une comparaison des systèmes de perpétuation des groupes domestiques dans les societés paysannes européenes. Archives Européenes de Sociologie, v. XXIII, n. 1, 1982, p. 39-72.

BARTHELEMY, Tiphaine. Les modes de transmission du patrimoine. Synthèse des travaux effectués depuis quinze ans par les ethnologues de la France. Études Rurales, v. 110-111-112, 1988.

BOTTOMORE, Tom (ed). Dicionário do pensamento marxista. Rio de Janeiro: Jorge Zahar Editor, 1988.

BOUCHARD, Gérard. L'étude des structures familiales préindustrielles: pour un renversement des perspectives. Revue d'histoire moderne et contemporaine, v. 28,1981 , p. $544-571$.

BOUCHARD, Gérard. Les systèmes de transmission des avoirs familiaux et le cycle de la société rurale au Québec du XVII au XXe siècle. Histoire sociale - Social history, v. 16, n. 31, 1983, p. 35-60.

BOUCHARD, Gérard; DICKINSON, John; GOY, Joseph (dirs). Les exclus de la terre en France et au Québec XVIIe-XXe siècles: la reproduction familiale dans la différence. Sillery: Septentrion, 1998.

BOURDIEU, Pierre. Célibat et condition paysanne. Études Rurales, n. 5-6, 1962, p. 32-135.

BOURDIEU, Pierre. Das regras às estratégias. In: Coisas ditas. São Paulo: Brasiliense, 1990.

CONGOST, Rosa. Tierras, leyes, historia: estudios sobre 'la gran obra de la propriedad'. Barcelona: Critica, 2007.

COSTA, Iraci del Nero. Notas sobre a posse de escravos nos engenhos e engenhocas fluminenses (1778). Revista do Instituto de Estudos Brasileiros, n. 28, 1988.

DÉPATIE, Sylvie. La transmission du patrimoine au Canada (XVIIe -XVIIIe siècle): qui sont les défavorisés? RHAF: Revue d'Histoire de l'Amérique Française, v.

\footnotetext{
${ }^{62}$ PEDROZA, Manoela. A economia moral de uma dinâmica agrária de tipo tradicional: um estudo sobre a manutenção de reciprocidades desiguais em terras comuns (freguesia de Campo Grande, Rio de Janeiro, século XIX). Mana: Revista do Programa de Antropologia Social da UFRJ, em avaliação.
} 
54, n. 4, 2001, p. 558-570.

DICKINSON, John. Destins familiaux dans de gouvernement de Montréal sous le régime français: les Brunet. In: BOUCHARD, Gérard et al (ed.). Les exclus de la terre en France et au Québec XVIIe-XXe siècles: la reproduction familiale dans la différence. Sillery: Septentrion, 1998.

FRAGOSO, João Luís Ribeiro. A nobreza da República: notas sobre a formação da primeira elite senhorial do Rio de Janeiro (séculos XVI e XVII). Topoi: Revista de História do Programa de Pós-Graduação em História Social da UFRJ, v. 1, 2000.

FRAGOSO, João Luís Ribeiro. Para que serve a história econômica. Estudos Históricos, v. 29, 2002.

FRAGOSO, João Luís Ribeiro. A nobreza vive em bandos: a economia política das melhores famílias da terra do Rio de Janeiro (século XVII). Algumas notas de pesquisa. Tempo: Revista do Departamento de História da UFF, v. 8, n. 15, 2003.

FRAGOSO, João Luís Ribeiro. Principais da terra, escravos e a República: o desenho da paisagem agrária do Rio de Janeiro seiscentista. Ciência e Ambiente, v. 33, 2006.

FRAGOSO, João Luís Ribeiro. Capitão Manuel Pimenta Sampaio, senhor do Engenho do Rio Grande, neto de conquistadores e compadre de João Soares, pardo: notas sobre uma hierarquia social costumeira (Rio de Janeiro, 1700 - 1760). In: XXIII Simpósio Nacional da ANPUH. São Leopoldo, RS., 2007.

FRIDMAN, Fania. Donos do Rio em nome do rei: uma história fundiária da cidade do Rio de Janeiro. Rio de Janeiro: Jorge Zahar, 1999.

FRÓES, Jose Nazareth de Sousa e GELABERT, Odaléa Ranauro Ensenat. Rumo ao Campo Grande: por trilhas e caminhos. Rio de Janeiro: sem editora, 2004.

HAMEISTER, Martha Daisson. Para dar calor à nova povoação: estudo sobre estratégias sociais e familiares a partir dos registros batismais da vila do Rio Grande (1738-63). Tese de doutorado, PPG História, UFRJ, Rio de Janeiro, 2006.

HESPANHA, António Manuel. A mobilidade social na sociedade de Antigo Regime. Tempo, v. 11, n. 21, 2006, p. 121-143.

HESPANHA, António Manuel e XAVIER, Ângela Barreto. A representação da sociedade e do poder. In: MATTOSO, José (ed). História de Portugal. Lisboa: Estampa, 2006.

LARA, Silvia Hunold e MENDONÇA, Joseli Maria Nunes (orgs). Direitos e justiça no Brasil: ensaios de história social. Campinas: Unicamp, 2006.

LEVI, Giovanni. Centro e periferia di uno stato assoluto: tre saggi su Piemònte e Liguria in età moderna. Torino: Rosenberg and Sellier, 1981.

LEVI, Giovanni. Carrières d'artisans et marché du travail à Turin (XVIII-XIX siècles). Annales ESC, ano 45, n. 6, 1990, p. 1.351-1.402.

MALATESTA, Maria. Le aristocrazie terriere nell'Europa contemporanea. Roma/ 
Bari: Editori Laterza, Quadrante Laterza 101,1999.

MARTINS, José de Sousa. A vida privada nas áreas de expansão da sociedade brasileira. In: Novais, F. A. e SCHWARZ, L. M. (eds). História da vida privada no Brasil: Contrastes da intimidade contemporânea. São Paulo: Companhia das Letras, 1994. MARTINS, José de Souza. O cativeiro da terra. São Paulo: Hucitec, 1986.

MARTINS, José de Souza. Fronteira: a degradação do outro nos confins do humano. São Paulo: Hucitec, 1997.

MATTOS, Ilmar Rohloff de. Tempo saquarema: a formação do Estado imperial. São Paulo: Hucitec, 1987.

MELO, Hildete Pereira e MARQUES, Teresa Cristina Novaes. A partilha da riqueza na ordem patriarcal. Revista de Economia Contemporânea, v. 5, n. 2, 2001.

MOMBEIG, Pierre. Pioneiros e fazendeiros de São Paulo. Tradução de Ary França e Raul Andrade e Silva. São Paulo: Hucitec - Polis, 1984.

ORDENAÇÕES FILIPINAS. Rio de Janeiro: Editor Cândido Mendes deAlmeida, 1870.

PAOLIELLO, Renata Medeiros. As tramas da herança: da reprodução camponesa às atualizações dos sentidos da transmissão da terra. Tese de doutorado, PPG Antropologia Social, USP, São Paulo, 1998.

PEDROZA, Manoela. Terra de resistência: táticas e estratégias camponesas nos sertões cariocas (1950-1968). Dissertação de mestrado, PPG História, UFRGS, Porto Alegre, 2003.

PEDROZA, Manoela. Engenhocas da moral: uma leitura sobre a dinâmica agrária tradicional. Tese de doutorado, PPG Ciências Sociais, Unicamp, Campinas, 2008.

PEDROZA, Manoela. A economia moral de uma dinâmica agrária de tipo tradicional: um estudo sobre a manutenção de reciprocidades desiguais em terras comuns (freguesia de Campo Grande, Rio de Janeiro, século XIX). Mana: Revista do Programa de Antropologia Social da UFRJ, em avaliação.

POLANYI, Karl. A grande transformação: as origens da nossa época. Rio de Janeiro: Campus, 1980.

RHEINGANTZ, Carlos Grandmasson. Primeiras famílias do Rio de Janeiro. Rio de Janeiro: Livraria Brasiliana, 1965.

SAMPAIO, Antônio Carlos Jucá de. Na encruzilhada do império: hierarquias sociais e conjunturas econômicas no Rio de Janeiro (1650-1750). Rio de Janeiro: Arquivo Nacional, Prêmio Arquivo Nacional de Pesquisa, 17, 2003.

SANTOS, Noronha. As freguesias do Rio Antigo. Rio de Janeiro: O Cruzeiro, 1965. SILVA, Francisco Carlos Teixeira e LINHARES, Maria Yedda. Região e história agrária. Estudos históricos, v. 8, n. 15, 1995.

SILVA, Maria Beatriz Nizza da. Sistema de casamento no Brasil colonial. São Paulo: Edusp, Coleção Coroa Vermelha,1984. 
SILVA, Sergio. Expansão cafeeira e origens da indústria no Brasil. São Paulo: Alfa Omega, 1976.

THOMPSON, Edward Palmer. Costumes em comum. São Paulo: Companhia das Letras, 1998.

VARELA, Laura Beck. Das sesmarias à propriedade moderna: um estudo de história do direito brasileiro. Rio de Janeiro: Renovar, 2005.

VELHO, Otávio Guilherme. Capitalismo autoritário e campesinato. São Paulo: Difel, 1974. 